\title{
ARSENIC CONTAMINATED GROUNDWATER IN CHINA AND ITS TREATMENT OPTIONS, A REVIEW
}

\author{
SAnjRani, M. A. ${ }^{1}-$ Zhou, B. ${ }^{1}-$ ZhaO, H. ${ }^{1}-$ Bhutto, S. A. ${ }^{2}-$ Muneer, A. S. ${ }^{2}-$ XiA, S. B. ${ }^{1 *}$ \\ ${ }^{1}$ School of Resources and Environmental Engineering, Wuhan University of Technology, \\ Wuhan, P.R. China \\ (e-mail:manzoor.geo@gmail.com; boxunzhou@foxmail.com; zhaoheng0802@126.com; \\ xiashibin@126.com)
}

${ }^{2}$ School of Environmental Studies, China University of Geosciences, Wuhan, P.R. China (e-mail:b_seeratua@yahoo.com; muneer.geo@gmail.com)

*Corresponding author

e-mail:xiashibin@126.com

(Received $19^{\text {th }}$ Oct 2018; accepted $2^{\text {nd }}$ Jan 2019)

\begin{abstract}
A high concentration of arsenic in groundwater is a worldwide problem, high concentration of arsenic in groundwater has been documented as a major health issue around the globe. According to WHO standard, the maximum contamination level for total arsenic in water is $10 \mu \mathrm{g} / \mathrm{L}$. China is one of the most affected country facing health issues because of arsenic contamination in groundwater that is often greater than established limits for human health. Although arsenic is present in several geographical regions in mainland China, Northern China has been identified as high-risk area. It has been estimated that 19.6 million people are at risk of being exposed to arsenic contaminated groundwater - especially rural areas, as those communities use groundwater for drinking water and household chores. To overcome the aforementioned problem, it is important to know the actual concentration level of arsenic in China and introduce a strategy to remove arsenic contamination. This paper provides a comprehensive overview on arsenic contamination status, sources and exposure pathways in China. It also aims to review the arsenic removal technologies which are easily available. Furthermore, it can be a useful resource for researchers as well as policy makers to identify and investigate useful treatment options.
\end{abstract}

Keywords: water pollution, arsenic poisoning, human health, water treatment, remedy, China

\section{Introduction}

The term water pollution usually refers to the introduction of physical, chemical, or biological materials in a body of water which affects its usage in the future. Water pollution has different types of contaminants, from which arsenic is a more poisonous and harmful one. Arsenic is the 12th most common element in nature and it usually appears in three allotropic forms including black, yellow and gray. If heated, it rapidly oxidizes to arsenic trioxide $\left(\mathrm{As}_{2} \mathrm{O}_{3}\right)$ and has a garlic odor (Fendorf et al., 2010a). Arsenic is also known as the "King of Poisons". It is classified as carcinogen, mutagens and teratogen. Generally, in groundwater, natural occurrences of high arsenic levels were reported in aquifers - especially unconsolidated sediment aquifers throughout the world and have been connected to several adverse health effects. Arsenic content in water can harm the immune system, kidney, lungs and liver. In addition to this, it causes bladder cancers. Due to these major health risks, World Health Organization (WHO, 2004) has established a standard value $(10 \mu \mathrm{g} / \mathrm{L})$ which states that the maximum arsenic contaminant level in water for drinking water should not exceed $10 \mu \mathrm{g} / \mathrm{L}$. Arsenic originates from different sources particularly geological surroundings such as a polluted environment, polluted bodies containing manganese oxides, irons, and arsenic-rich 
minerals. There are extensive scientific research-based investigations in high arsenic level in groundwater all over the world (Sanjrani et al., 2017).

Arsenic contamination has been found in more than 70 countries but, the countries which are at the top of list for arsenic poisoning in groundwater are: India, Cambodia, Vietnam, Chile, Argentina, America and China. In other parts of the world, high concentration of arsenic has also been found in the bodies of water, including parts of the USA, Chile, Mexico, Argentina, Hungary, Japan, Canada, Poland, Ghana, Bangladesh, India, China, Afghanistan, Pakistan, Myanmar, Taiwan, are also reported to have arsenic contaminated water (WHO, 1999; Nickson et al., 2000; Niedzielski et al., 2001; Smedley and Kinniburgh, 2002; Guo and Wang, 2005; Marchiset-Ferlay et al., 2012; Ahmad et al., 2013; Horner and Beauchemin, 2013; Oguri et al., 2014; Quratul-Ain et al., 2017; Sanjrani et al., 2018; Zheng, 2018). In 2004, World health organization (WHO, 2004) issued a list of countries with arsenic issues in water. The list is shown in Table 1.

Table 1. List of countries affected by arsenic contamination

\begin{tabular}{c|c}
\hline Americas & $\begin{array}{c}\text { United States of America, Alaska, Chile, Peru, Dominica, Honduras, Nicaragua, } \\
\text { Argentina, El Salvador, Mexico }\end{array}$ \\
\hline Africa & South Africa, Ghana, Zimbabwe \\
\hline Asia & $\begin{array}{c}\text { India, Bangladesh, Japan, China, Cambodia, Iran, Pakistan, Myanmar, Vietnam, Nepal, } \\
\text { Thailand }\end{array}$ \\
\hline \multirow{2}{*}{ Europe } & $\begin{array}{r}\text { United Kingdom, Austria, Finland, Romania, France, Greece, Italy, } \\
\text { Hungary, Russia, Croatia, Serbia, Germany }\end{array}$ \\
\hline Pacific & New Zealand, Australia \\
\hline
\end{tabular}

Among the countries that produce arsenic, China is the top producer of white-arsenic who produces almost $50 \%$ world-share, followed by other countries such as Peru, Chile and Morocco. Studies have identified some areas of high-risk for arsenic contamination belong to northern areas of China, including the Xinjiang province, the Shanxi province, the Inner-Mongolia province, the Henan province, the Shandong province and the Jiangsu province. All of the provinces contain naturally occurring arsenic with a concentration exceeding $10 \mu \mathrm{g} / \mathrm{L}$ (Nickson et al., 1998; Smith et al., 2000; Sun et al., 2003; Li, 2005; Xie et al., 2008; He and Charlet, 2013). In recent decades, it estimated that more than 19.6 million people are likely to be at risk of waterborne diseases. Moreover their lives are in danger due to arsenic contamination in groundwater (Rodríguez-Lado et al., 2013). There is collaboration between Switzerland and China, a special team is conducting research on ground-breaking studies, using geological maps and geological data to pin-point areas more likely to be put at high-risk due to the poison (SWI, 2012). The conducted study shows the increasing health-threat in China, including those areas which were not previously at risk. Each year, approximately 19.0 million Chinese people get sick because of polluted water from either industrial or agricultural activities, which cause approximately 60,000 premature deaths (Sun et al., 2011; IWR, 2011). There is a particular health threat in northern China because communities who belong to this area mostly depend on groundwater for their lives. China is a big country with more than 10 million drinking wells which are difficult to screen. It is expected that recent advanced research will help policy makers and authorities in China manage their well-screening programs as contaminated wells need to be treated. (Chan and Griffiths, 2010; WHO, 2011; CR, 2013). The situation needs be 
quickly placed under control and there is an urgent need to arrange drinking water free of arsenic to communities who belongs to rural areas. In this regard, many different approaches may be applied for different bodies of water. Treatment options are available for arsenic contaminated water. These treatment options include pond water, surface water and harvesting rainwater. There are also other treatment possibilities such as to create a safe environment while also providing low-cost and small level fitted systems for removal of arsenic from groundwater for removal of arsenic from groundwater. In rural areas, it may not be feasible to install such a system for many families; however with the government supports rainwater harvesting could be possible option to acquire safe water for more households (Cheng et al., 2004; Sarkar et al., 2010).

Around the world, arsenic is being removed in many areas. With the introduction of many arsenic removal technologies, it is easy to treat the water. These technologies helps in arsenic remediation, including activated alumina, ion exchange, membrane filtration, reverse osmosis, modified coagulation-filtration, and also enhanced limesoftening. However, affected rural areas or developing areas need ideal and effective technology that should be versatile, low-cost, transferable and adoptable for both community application and household units (USEPA, 2000; Berg et al., 2006; Visoottiviseth and Ahmed, 2008).

While considering the serious issues of arsenic pollution in groundwater of several regions of China and it treatment technologies, this paper aims to review recent status of arsenic contamination in several regions of China which are highly affected exceeding WHO standard level $10 \mathrm{ug} / \mathrm{L}$. This paper also aims to review about its sources and reasons for mobilization, exposure pathways as well as suitable technologies for arsenic removal which can be applied for treatment. This paper will prove to be a helpful and useful resource for readers and researchers or policy makers in regards to the identification and investigation for the better solutions.

\section{Contamination level of arsenic and affected areas in China}

The distribution of arsenic concentration drawn (as shown by contour lines) in groundwater of different provinces in China and is presented in Figure 1. Investigations have identified several basin areas around China where groundwater frequently contains $>10 \mu \mathrm{g} / \mathrm{L}$ arsenic, which exceeds the current drinking water standard established by the Chinese Environmental Protection Agency for Public Water Supply. Every province has different arsenic range; after reviewing several studies, a map has been drawn to this review paper to help one understand the situation of arsenic in every province clearly. In the map, the most affected regions with arsenic contaminated aquifers indicated by the color red. Arsenic pollution occurs in many provinces (Beijing, Guangdng, Gansu, Henan, Hunan, Heilongjiang, Inner Mongolia, Jilin, Jiangsu, Liaoning, Ningxia, Qinghai, Sichuan, Shandong, Shanxi, Taiwan, Xinjiang, Yunnan and Zhejiang) (Table 2). It is important to take note of the method in which arsenic contamination has been detected in water samples. Many different organizations (government and nongovernment groups) have employed both field-kits and in-laboratory research to identify arsenic contaminated waters. These studies have yielded accurate results. These findings are based on the data from (Tseng et al., 1968; Huang et al., 1985; Wang et al., 1993; Luo, 1993; Jin et al., 2003; Chen et al., 2003; Pang et al., 2003; Liu et al., 2003; Deng et al., 2004; Guo and Wang, 2005; Pei et al., 2005; Shen et al., 2005; Li et al., 2006; Luo et al., 2006; Yu et al., 2007; Yang et al., 2008; Guo et al., 2008; Xie et al., 
2008; Han et al., 2009; Zhu et al., 2009; Liu et al., 2009; Qin and Xu, 2010; Huang et al., 2010; Li et al., 2010; Jiang et al., 2010; Hao and Xing, 2010; Bo and Luo, 2010; He et al., 2010; Shi et al., 2010; Tang et al., 2010; Zhang et al., 2010; Han et al., 2010; Wang et al., 2010; Yang et al., 2011; Xie et al., 2011al., 2011b; Bian et al., 2012; Chen et al., 2012; Wen et al., 2013; Gao et al., 2013; Guo, 2013; Guo, 2014) previously published literatures. Most affected areas to date, rounded about 3998 individuals with arsenicosis, including children most who have been identified living in rural areas of the Shanxi province, in Northern, China (Wang et al., 2007; Sun et al., 2011).

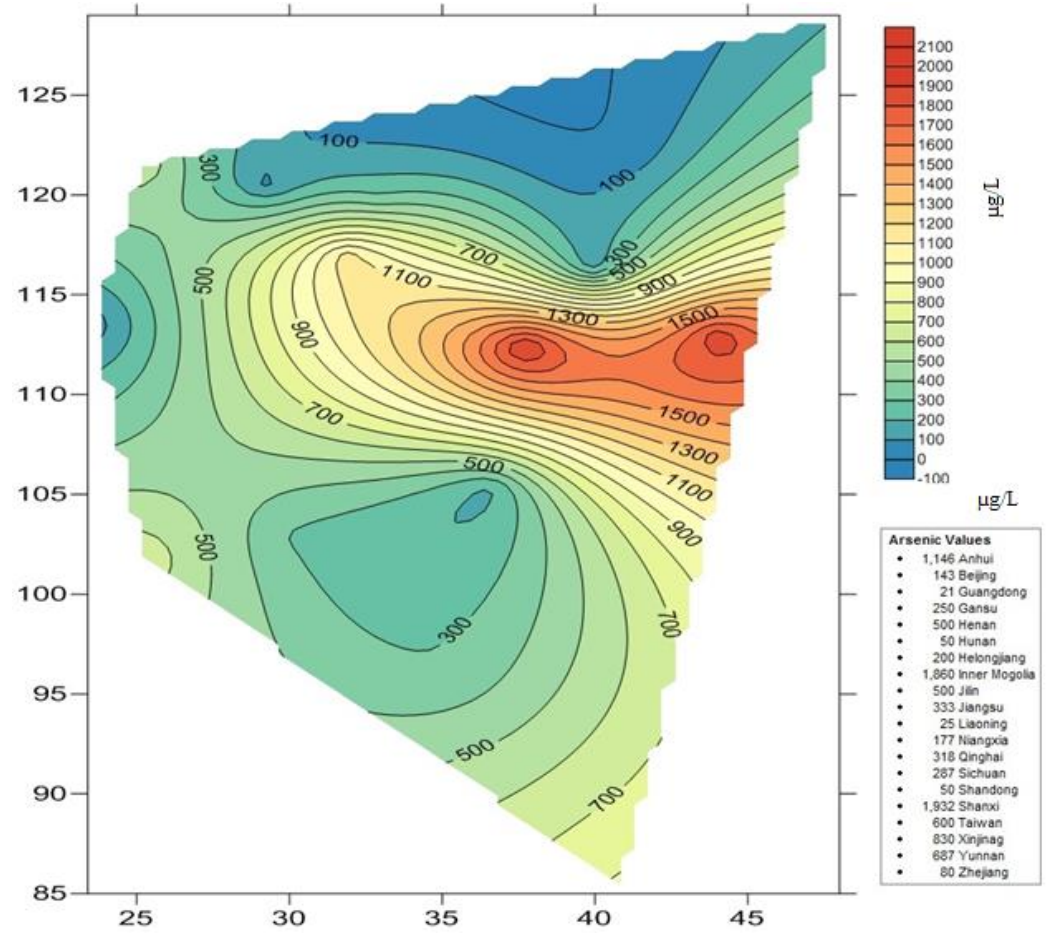

Figure 1. Contamination level of arsenic

The arsenic problem in China was first documented in the late 1970's and early 1980's; arsenic-specific changes were diagnosed in the Kuitun area of the Xinjiang province. Later in 1989, Inner Mongolia was reported as another serious arsenicosis area, followed by Shanxi province around 1994 (SWI, 2012, Unicef). Researchers are still interested in some areas because the arsenic value may vary every year especially in Shanxi province of China. Moreover, the Shanxi province has been recognized as a famous area with significant exposure in terms of high arsenic concentration (up to $1932 \mu \mathrm{g} / \mathrm{L}$ ) level (Figure 2). According to new recent research the area of China with the highest arsenic content is Datong Basin. Its maximum arsenic content $(2610.9 \mu \mathrm{g} / \mathrm{L})$ was detected at the depth of $26.8 \mathrm{~m}$ (Sun, 2004; Xie et al., 2013). The Shanxi province - especially Datong Basin - has a high level of arsenic in groundwater, which many use as drinking water. Datong Basin is one of the most water-stressed regions (Xie et al., 2011c), in the world. In this water stressed region, surface water supply is usually very limited; therefore, alternative sources for portable, drinking water and house hold and irrigation water is mostly groundwater. The nexus of population growth and climate change in the region has exacerbated the use of groundwater resources with dramatic 
impact both on its quality and quantity (Wang et al., 2009). The current challenge is to understand the process and also focus on how to decontaminate the widely occurring geogenic arsenic in groundwater in this region of China so the water supply meets the required WHO standards (Xie et al., 2012).

Table 2. Arsenic information in provinces of China

\begin{tabular}{|c|c|c|c|c|}
\hline S. No & Province & Areas & $\begin{array}{c}\operatorname{Max} A s \\
(\mu \mathrm{g} / \mathrm{L})\end{array}$ & References \\
\hline 1 & Anhui & Fuyang,Dangshan,Wuhe, Tianchang & 1146 & $\begin{array}{c}\text { Wen et al., 2013; Guo, 2014; Sun et al., 2011; } \\
\text { Jin et al., 2003; Li et al., 2006; Qin and Xu, } \\
\text { 2010; Yu et al., 2007 }\end{array}$ \\
\hline 2 & Beijing & Shunyi & 143 & $\begin{array}{l}\text { Guo, 2014; Wen et al., 2013; Jin et al., 2003; } \\
\text { Pang et al., 2003 }\end{array}$ \\
\hline 3 & Guangdng & Fuoshan & $>21$ & $\begin{array}{l}\text { Guo, 2014; Huang et al., 2010, 2014; Wen et } \\
\text { al., 2013; Fan, 2014 }\end{array}$ \\
\hline 4 & Gansu & Yumen, Qin'an, Datong, Menyuan & $\geq 250$ & $\begin{array}{l}\text { Guo, 2014; Wen et al., 2013; Jin et al., 2003; } \\
\text { Yu et al., 2007 }\end{array}$ \\
\hline 5 & Henan & Qixian & $\geq 500$ & $\begin{array}{c}\text { Guo, 2014; Wen et al., 2013; Yu et al., 2007; } \\
\text { Li et al., 2010 }\end{array}$ \\
\hline 6 & Hunan & Shimen & $\geq 50$ & Guo, 2014; Wen et al., 2013; Yu et al., 2007 \\
\hline 7 & Heilongjiang & $\begin{array}{l}\text { Lindian, Zhaoyuan, Dorbod, Anda as } \\
\text { parts of Songnen Plain }\end{array}$ & 200 & $\begin{array}{l}\text { Guo, 2014; Wen et al., 2013; Yu et al., 2007; } \\
\text { Hao and Xing, } 2010\end{array}$ \\
\hline 8 & InnerMongolia & \begin{tabular}{|c|} 
Dengkou, Linhe, \\
Hangjinhouqi,Wuyuan,Wulateqianqi, \\
Wulatehouqi,Wulatezhongqi, \\
Tuoketuo, Tumotezuoqi, Tumoteyouqi, \\
Alashanzuoqi, as Hetao Plain; \\
Keshenketengqi, \\
Sunidyouqi, Sonidzuoqi, Naimanqi, \\
Ewenkizuzizhiqi, \\
Xinbaragzuoqi, Taibusqi, Horinger \\
\end{tabular} & 1860 & $\begin{array}{l}\text { Guo, 2008, 2014; Wen et al., 2013; Bo and } \\
\text { Luo, 2010; He et al., 2010; Luo et al., 2006; } \\
\text { Luo, 1993; Yang et al., } 2008\end{array}$ \\
\hline 9 & Jilin & $\begin{array}{c}\text { Tongyu, Yaonan, Daan, Shuangliao as } \\
\text { parts of Songnen Plain }\end{array}$ & $\geq 500$ & $\begin{array}{c}\text { Guo, 2014; Wen et al., 2013; Yu et al., 2007; } \\
\text { Bian et al., 2012; Tang et al. } 2010\end{array}$ \\
\hline 10 & Jiangsu & Sihong, Nantong, Xuyi & 333 & $\begin{array}{c}\text { Guo, 2014; Wen et al., 2013; Han et al., 2009; } \\
\text { Zhang et al., } 2010\end{array}$ \\
\hline 11 & Liaoning & Kangping & 25 & Guo, 2014; Wen et al., 2013; Liu et al., 2003 \\
\hline 12 & Ningxia & $\begin{array}{c}\text { Pingluo, Helan, Huinun, Qingtongxia, } \\
\text { Xixia as parts of Yinchuan Plain, } \\
\text { Zhongwei, Zhongning } \\
\end{array}$ & 177 & $\begin{array}{l}\text { Guo, 2014; Wen et al., 2013; Yu et al., 2007; } \\
\text { Han et al., } 2010\end{array}$ \\
\hline 13 & Qinghai & Guide, Datong, Menyuan & 318 & $\begin{array}{c}\text { Guo, 2014; Wen et al., 2013; Jin et al., 2003; } \\
\text { Shi et al., 2010 }\end{array}$ \\
\hline 14 & Sichuan & Jinchuan, Luding & 287 & Guo, 2014; Wen et al., 2013; Deng et al., 2004 \\
\hline 15 & Shandong & $\begin{array}{c}\text { Dongchangfu, Yanggu, Yuncheng, } \\
\text { Tengzhou, Jiaxiang, Guanxian, } \\
\text { Liangshan } \\
\end{array}$ & $\geq 50$ & $\begin{array}{l}\text { Guo, 2014; Wen et al., 2013; Yu et al., 2007; } \\
\text { Shen et al., } 2005\end{array}$ \\
\hline 16 & Shanxi & \begin{tabular}{|c|} 
Shanyin, Yingxian, Shuozhou as parts \\
of Datong Basin; Fenyang, Xiaoyi, \\
Pingyao, Wenshui, Jiexiu, Yuci,Qixian, \\
Tianzhen,Xiaodianqu, Qingxu, Loufan, \\
Dingrang, Yicheng, Yanhu, Yongji, \\
Tengchong, Gengma, Eryuan \\
\end{tabular} & 1932 & $\begin{array}{l}\text { Guo et al., 2005, 2013, 2014; Wen et al., } \\
\text { 2013; Jin et al., 2003; Pei et al., 2005; Wang } \\
\text { et al., 2010; Xie et al., 2008, 2011a, 2011b }\end{array}$ \\
\hline 17 & Taiwan & Jiayi,Tainan & 600 & $\begin{array}{l}\text { Guo, 2014; Wen et al., 2013; Li et al., 2006; } \\
\text { Chen et al., 2003; Tseng et al., } 1968\end{array}$ \\
\hline 18 & Xinjiang & $\begin{array}{l}\text { Kuiteng,Wusu, Tacheng, Sulei, Bachu, } \\
\text { Luntai, Awat, Shawan, Bohu }\end{array}$ & 830 & $\begin{array}{c}\text { Guo, 2014; Wen et al., 2013; Yu et al., 2007; } \\
\text { Huang et al., 1985; Wang et al., 1993; Zhu et } \\
\text { al., } 2009\end{array}$ \\
\hline 19 & Yunnan & Changning, Mengla & 687 & $\begin{array}{c}\text { Guo, 2014; Yu et al., 2007; Chen et al., 2012; } \\
\text { Liu et al., 2009; Yang et al., 2011 }\end{array}$ \\
\hline 20 & Zhejiang & Nanxun, Tongxiang & 80 & Guo, 2014; Jin et al., 2003; Jiang et al., 2010 \\
\hline
\end{tabular}




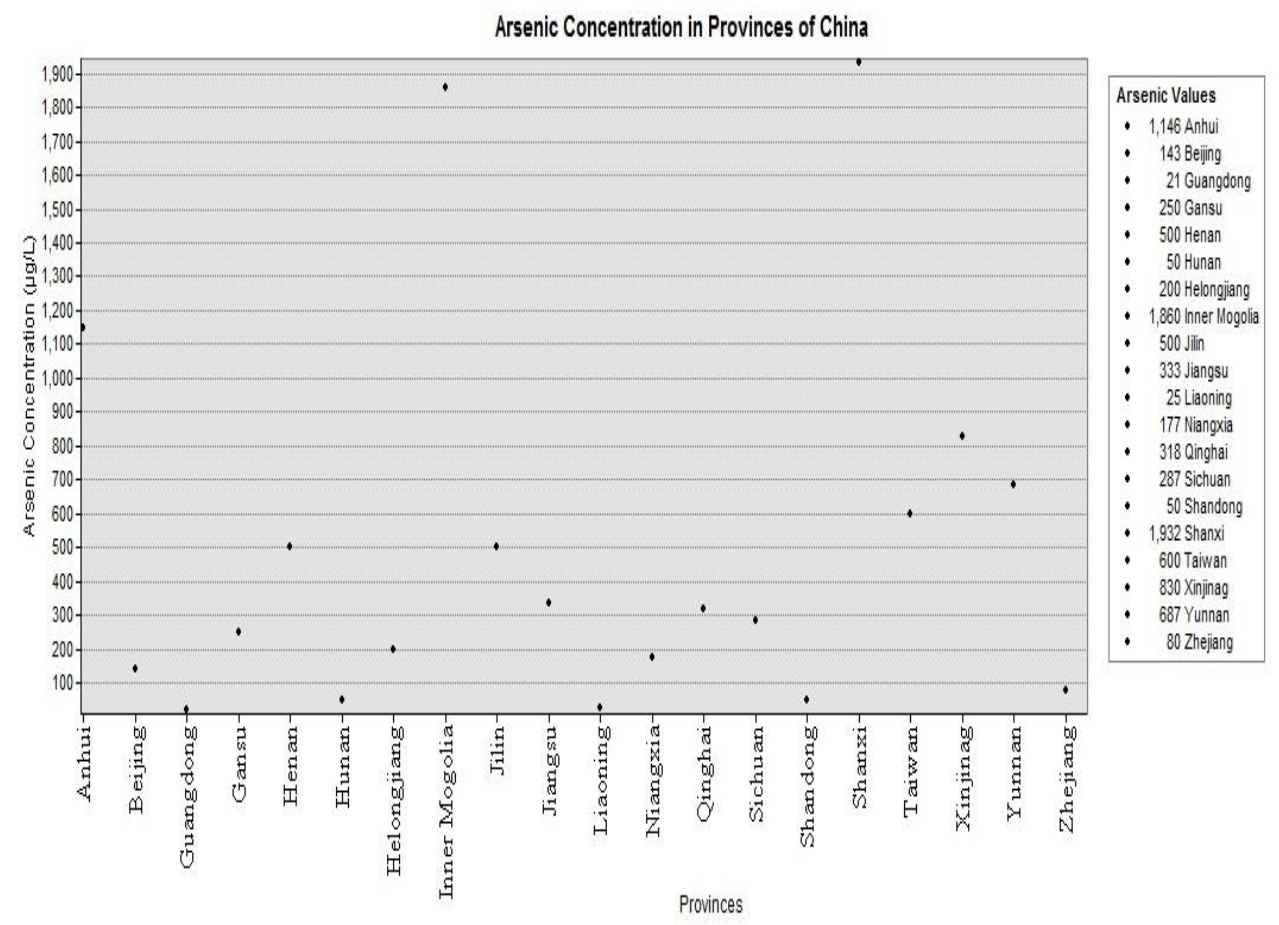

Figure 2. Arsenic contamination level in different provinces of China

\section{Sources and Mobility of Arsenic}

Natural occurrences of arsenic-contaminated groundwater have brought severe associated health risks. Arsenic may enter water bodies, air and land by transportation through water runoffs and wind-blown dust etc. Arsenic in the atmosphere comes from geological activities such as volcanoes, and organisms - especially microorganisms and industrial activity in as the burning of fossil fuels as well as other activities. It has been previously accepted that the major sources of arsenic contamination in the groundwater of China are geological deposits, which is present in 200 minerals. Except geo and mining environments, other two main environmental conditions are known to be linked to natural arsenic in groundwater systems (Deng et al., 2009) (i) aerobic alkaline environments in closed basins in semiarid and in arid regions, where $\mathrm{pH}$ is high and leads to alkaline desorption of arsenic from mineral oxides, and (ii) aquifers are in under reducing conditions, where the release of arsenic is closely related to reductive dissolution of arsenic-bearing iron (hydro)oxides in sediments. In groundwater, there are two common types of forms of arsenic including Arsenite and Arsenate. Arsenite is always present under more reducing conditions whereas arsenate almost always present under oxidizing conditions. Several related studies in China have indicated the arsenicenriched groundwater to be classified as reducing conditions (Smedley et al., 2003; Guo and Wang, 2005; Zhang and Guo, 2007; Guo et al., 2010; Hagiwara et al., 2011; Xie et al., 2013), particularly in the arid regions, where such conditions in alluvial and lacustrine aquifer sediments are often concomitant with high salinity and/or alkalinity. In some areas, mostly Taiwan, arsenic release has also been associated with anoxic aquifers (Lee et al., 2009).

As stated earlier, previous studies indicate that the sediment-water interactions cause geogenic enrichment of arsenic in groundwater. Furthermore, arsenic content ranging 
from 1 to $10 \mathrm{mg} / \mathrm{kg}$ can cause enrichment of dissolved arsenic in groundwater may exceed $1000 \mu \mathrm{g} / \mathrm{L}$ (Smedley and Kinniburgh, 2002). It is critical to document the source of arsenic in sedimentary aquifers to improve our understanding of arsenic enrichment mechanism. Efforts have been made by different organizations to document the potential sources of arsenic in aquifers and it has been indicated that the sources of arsenic in sedimentary aquifers are related to chemical weathering of the minerals, which contain arsenic within it (Saunders et al., 2004; Zheng, 2007). Studies have reviewed and explained the link between natural arsenic contaminated aquifers and weathering. Several minerals related to arsenic and occurrences are documented in detail in Table 3.

Table 3. Arsenic minerals occurring in nature

\begin{tabular}{|c|c|c|c|}
\hline S. No & Mineral & Composition & Occurrence \\
\hline 1 & Native arsenic & As & $\begin{array}{l}\text { Hydrothermal veins and deposits that contain other arsenic } \\
\text { minerals }\end{array}$ \\
\hline 2 & Niccolite & NiAs & $\begin{array}{c}\text { A minor-component of Ni-Cu ores in high- } \\
\text { temperaturehydrothermal veins }\end{array}$ \\
\hline 3 & Safflorite & $(\mathrm{Co}, \mathrm{Fe}) \mathrm{As} 2$ & Hydrothermal veins \\
\hline 4 & Realgar & AsS & $\begin{array}{l}\text { Vein deposits often associated with orpiment clays, and lime } \\
\text { stones, deposits from hot springs }\end{array}$ \\
\hline 5 & Orpiment & $\mathrm{As}_{2} \mathrm{~S}_{3}$ & $\begin{array}{c}\begin{array}{c}\text { 'Hydrothermal veins, hot springs, volcanic sublimation } \\
\text { products }\end{array} \\
\end{array}$ \\
\hline 6 & Cobaltite & CoAsS & $\begin{array}{l}\text { Medium-temperature hydrothermal deposits, metamorphic } \\
\text { rocks }\end{array}$ \\
\hline 7 & Arsenopyrite & FeAsS & $\begin{array}{l}\text { The most abundant arsenic mineral, dominantly in vein } \\
\text { sofhydrothermal origin, found in pegmatites, high- } \\
\text { temperature gold, quartz and tin veins, in contact } \\
\text { metamorphic sulfide deposits, also in gneisses, schist sand } \\
\text { other metamorphic rocks }\end{array}$ \\
\hline 8 & Arsenianpyrite & $\mathrm{Fe}(\mathrm{As}, \mathrm{S})_{2}$ & $\begin{array}{c}\text { Hydrothermal veins, accessory mineral in igneous rocks, } \\
\text { pegmatites and contact metamorphic deposits }\end{array}$ \\
\hline 9 & Lollingite & $\mathrm{FeAs}_{2}$ & $\begin{array}{l}\text { Mesothermal deposits associated with other sulfides and } \\
\text { calcite gaunge }\end{array}$ \\
\hline 10 & Tennantite & $(\mathrm{Cu}, \mathrm{Fe})_{12} \mathrm{As}_{4} \mathrm{~S}_{13}$ & Hydrothermal veins and contact metamorphic deposits \\
\hline 11 & Enargite & $\mathrm{Cu}_{3} \mathrm{AsS}_{4}$ & Hydrothermal vein deposits formed at medium temperatures \\
\hline 12 & Arsenolite & $\mathrm{As}_{2} \mathrm{O}_{3}$ & $\begin{array}{c}\text { Secondary mineral formed by oxidation of FeAsS, native } \\
\text { arsenic and other arsenic minerals }\end{array}$ \\
\hline 13 & Scorodite & $\mathrm{FeAsO}{ }_{4} \cdot 2 \mathrm{H}_{2} \mathrm{O}$ & $\begin{array}{c}\text { Secondary mineral formed by oxidation of arsenic-bearing } \\
\text { sulfides }\end{array}$ \\
\hline 14 & Annabergite & $(\mathrm{Ni}, \mathrm{Co})_{3}\left(\mathrm{AsO}_{4}\right)_{2} \cdot 8 \mathrm{H}_{2} \mathrm{O}$ & $\begin{array}{c}\text { Secondary mineral formed by the alteration of Co-Ni-bearing } \\
\text { arsenides and sulfides, in the oxidized zone of hydrothermal } \\
\text { mineral deposits }\end{array}$ \\
\hline 15 & Hoernesite & $\mathrm{Mg}_{3}\left(\mathrm{AsO}_{4}\right)_{2} \cdot \mathrm{H}_{2} \mathrm{O}$ & Secondary mineral, in limestone blocks and volcanic tuff \\
\hline 16 & Symplesite & $\mathrm{Fe}^{2+}{ }_{3}\left(\mathrm{AsO}_{4}\right)_{2} .8 \mathrm{H}_{2} \mathrm{O}$ & $\begin{array}{l}\text { Secondary mineral in the oxidized zone of some arsenic rich } \\
\text { Hydrothermal mineral }\end{array}$ \\
\hline 17 & Conichalcite & $\mathrm{CaCu}\left(\mathrm{AsO}_{4}\right) \mathrm{OH}$ & $\begin{array}{c}\text { Secondary mineral in the oxidized zone of } \mathrm{Cu} \text { deposits, and } \\
\text { alteration product of enargite }\end{array}$ \\
\hline
\end{tabular}

Source: Modified from (Smedley and Kinniburgh, 2002; Anthony et al., 1990; Anthony et al., 2000)

Although large areas such as the Tarim basin (Xinjiang), the Ejina basin (Inner Mongolia), the Heihe basin (Gansu), the Qaidam basin (Qinghai), the Northeastern plain (Inner Mongolia, Jilin, and Liaoning), and the North China plain (Henan and Shandong) are known as being potentially affected, the worst situation of arsenic problems in China has been documented in Inner Mongolia and the Datong Basin, where several studies have been conducted. More recently, the controlling factors 
(Saunders et al., 2004; Xie et al., 2008, 2009a, 2009b) have been documented to understand the arsenic mobilization in aquifers system at the Datong basin. Fehydroxides/oxides were the major causes for arsenic in aquifer systems at Datong (Xie et al., 2008, 2009a, 2009b). However, the source of the geogenic arsenic in some areas is a controversial issue and has yet to be determined. Although results of the preliminary geochemical survey have indicated that the bedrocks around the basin were the potential sources for arsenic in the aquifer system (Xie et al., 2013), more detailed work is still needed to answer this open question.

It is already generally accepted that the reduction of arsenic-bearing $\mathrm{Fe}$ oxides/hydroxides through organic carbon oxidation can be said to promote the mobilization of arsenic. However, the mechanisms involved are still not fully understood. Studies are being conducted to understand the processes controlling the mobilization of arsenic. Therefore, it is important to understand the transformation of Fe minerals within the aquifer system in order to elucidate the mechanisms involved in the release of arsenic into groundwater. Studies (Jiang, 2001; Xie et al., 2008, 2013) have shed a light on arsenic mobilization and the associated dissolution/precipitation and transformation of Fe minerals. Studies have presented Fe isotope compositions of Fe leached from aquifer sediments which were collected from a well-known arseniccontaminated site in China at the Datong Basin; the results demonstrate that in various $\mathrm{Fe}$ pools, the $\mathrm{Fe}$ isotopic composition may be produced through microbial $\mathrm{Fe}$ (III) reduction and the secondary $\mathrm{Fe}(\mathrm{II})$ phases formation. The Fe isotope compositions and the distinct arsenic concentrations in $\mathrm{HCl}$ extracted poor-crystalline $\mathrm{Fe}$ phases and crystalline $\mathrm{Fe}$ (III) provide a framework to interpret arsenic mobilization in aquifers in the Datong Basin, China (Jiang, 2001, Xie et al., 2008, 2013; Zhu et al., 2009; Lee et al., 2009).

Generally, Arsenic pyrites/ferrous hydroxides are arsenic-rich minerals which are stable in reducing environment under water-table and are mostly concentrated in organic deposits. However, the different anthropogenic activities accelerate the oxidation process and arsenic release from the minerals. Absorption onto iron hydroxide is not a problem, while adsorption of arsenic onto iron hydroxide returns to the reducedenvironment under the water-table and mixes with water and ultimately poisons the water. The hypothesis elaborates the recent phenomenon that the origin of arsenic-rich groundwater is human-made. Moreover, the different geological processes such as weathering, erosion, sedimentation, and use of irrigation and fertilizers accelerate the processes (Xie et al., 2008, 2009b, 2012; Hagiwara et al., 2011; Maity et al., 2012; Jiang, 2001).

\section{Exposure pathways and toxic effects of arsenic to human health}

Several studies have been conducted to document the toxicity of arsenic and its effects on human health in various arsenic-contaminated regions around the globe (Engel and Smith, 2004; Raven, 2009). Usually arsenic enters human-beings through two pathways; first, direct consumption of drinking water that contains arsenic and second, for populations not exposed to elevated arsenic in drinking water to have indirect contact through food intake and the cultivation of crops. Undetectable in its early stages, arsenic poisoning takes between 8 and 14 years to impact health, depending on the amount of arsenic ingested, nutritional status, and immune response of the individual (Raven, 2009; Fontcuberta et al., 2011). Toxicity depends on the amount of arsenic intake, which can be classified into acute, sub-acute and chronic toxicity 
respectively. Arsenic contamination in drinking-water threatens health around the world and affects an estimated amount of more than 150 million people. While around 110 millions belong to highly affected ten countries in South and South-east Asia including Bangladesh, Vietnam, China, Taiwan, Laos, Cambodia, Myanmar, India, Pakistan, and Nepal (WHO, 1999; Hsueh et al., 1995; Brammer, 2008; Raven, 2009; Fontcuberta et al., 2011). Recent studies have also documented that human intakes of arsenic, especially inorganic in a range of $0.05 \mathrm{mgL}^{-1}$ leads to arsenicosis. Arsenic is associated with a several non-neoplastic diseases, such as cerebrovascular disease, cardiac disease, leuco-melanosis and hyperker- atosis, diabetes mellitus, pulmonary disease and diseases of the capillaries, arteries and arterioles (Fontcuberta et al., 2011). Chronic arsenic ingestion from drinking water is known to cause skin cancer affected by arsenite and arsenate. Chronic exposure to inorganic As causes several disorders upon different biological systems such as the digestive system, respiratory system, cardiovascular system, hematopoietic system, endocrine system, renal system, neurological system, and reproductive system. These diseases ultimately increase the risk for bladder, kidney, liver, lung cancer, and diseases of the blood-vessels of the legs and feet, and possibly high blood pressure which is shown in Figure 3 (Mandal et al., 1996; Maharjan et al., 2005; Saha, 2009; Shukla et al., 2010; Fendorf et al., 2010b; Chakraborti et al., 2010; WHO, 2011).

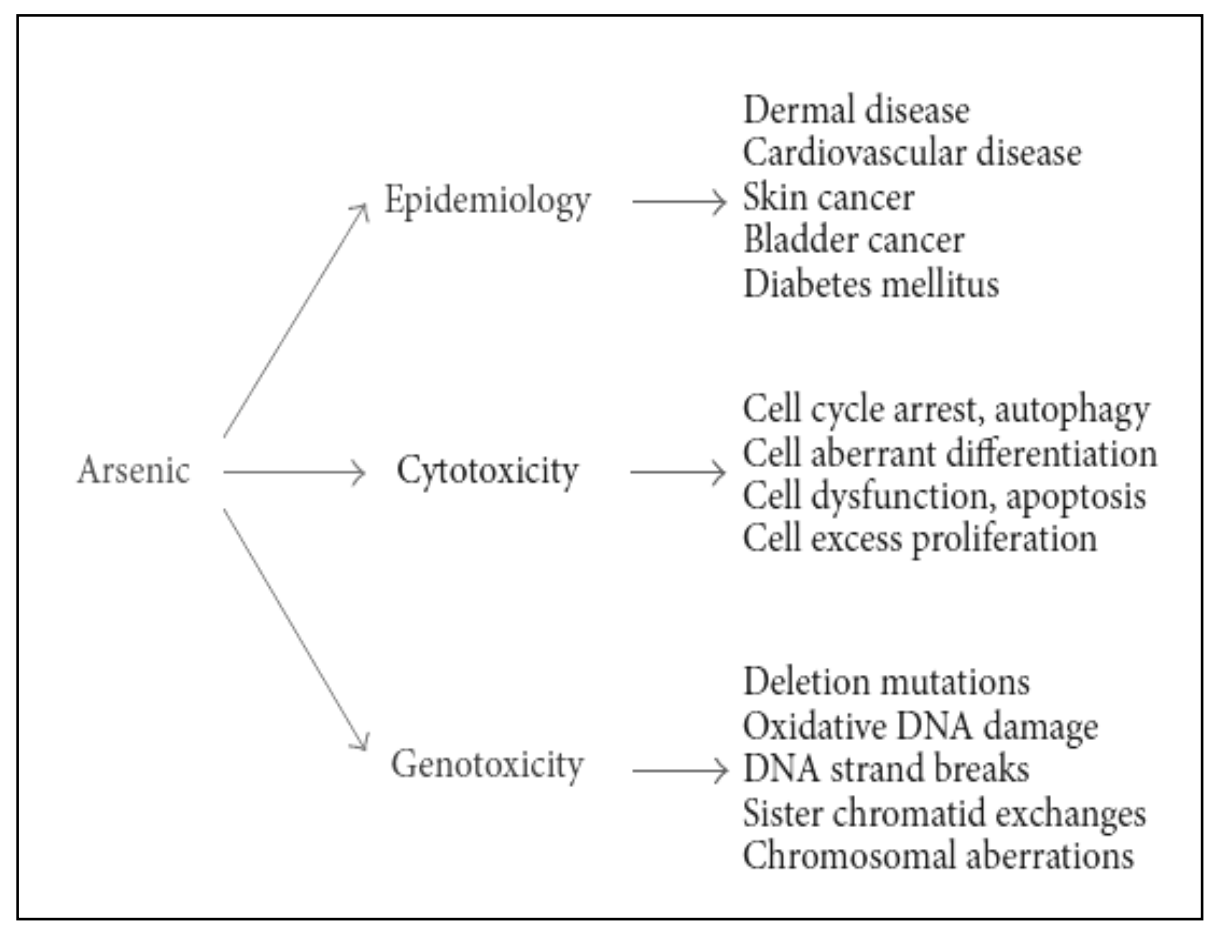

Figure 3. Arsenic toxicity in human (Saha, 2009; Shukla et al., 2010)

The major arsenicosis regions are presently documented in large deltas and along the largest rivers merging from the Himalayas (Fendorf et al., 2010a) such as in the Bengal delta (Chakraborti et al., 2010), other parts of India (Saha, 2009; Shukla et al., 2010), Nepal (Thakur et al., 2011), Pakistan (Malik et al., 2009), Myanmar, Vietnam, Cambodia (Berg et al., 2007; Polya et al., 2008) and China (He and Charlet, 2013). Therefore, arsenic free water is urgently needed to mitigate arsenic toxicity and protect 
the health and well being of people living in acute arsenic problem areas - especially in rural areas where the groundwater is the only source for drinking water. The populations exposed to to arsenic around the world are shown in the Table 4. It was first realized in the late 1970s and early 1908s that there were arsenic issues in China; firstly patients from Kuitun area of Xinjiang province were diagnosed to have arsenicosis. Later Inner Mongolia was documented as another areawith the worst arsenicosis in 1989, followed by the Shanxi province around 1994, and recently the Datong Basin has the worst arseni ccontamination levels, which has brought health risks communities belonging to rural areas (Sun, 2004; Kongkea et al., 2010, Xie et al., 2013, He and Charlet, 2013).

Table 4. Estimated Number of people exposed to arsenic contamination in selected countries

\begin{tabular}{c|c|c}
\hline Countries & Population exposed to As & Reference \\
\hline India & 102585 & \\
China & 31385 & \\
Bangladesh & 30969 & \\
Pakistan & 23202 & \\
Vietnam & 15603 & \\
USA & 6225 & WHO 1999, UNICEF \\
Italy & 5210 & \\
Mexico & 5041 & \\
Japan & 4910 & \\
Taiwan & 4133 & \\
Argentina & 2551 & \\
Cambodia & 2422 & \\
Nepal & 1465 & \\
Hungary & 1422 & \\
Canada & 1404 & \\
Chile & 1046 & \\
\hline
\end{tabular}

In China, several provinces have arsenic contamination in its groundwater, which crosses the standard range of $10 \mathrm{ug} / \mathrm{ml}$. However, epidemiological studies on the effects of arsenic exposure from drinking water on public health indicated a carcinogenic effect. As arsenic bring cancers of the skin, liver, lung, bladder and kidney, and probability, experts indicated that a concentration level of $50 \mu \mathrm{g} \mathrm{As} / \mathrm{L}$ could lead to cancer in 1 in 100 individuals. In the case of chronic poisoning, this deadly element accumulates in skin, hair and nails, resulting in strong pigmentation of hand and foot, also known as keratosis, and problems in other body system such as respiratory, neurological, high blood pressure, endocrine, cardiovascular and metabolic dysfunctions/disorders (Yunus et al., 2011; McClintock et al., 2012; Ferlay et al., 2015).

\section{Treatment options for remediation of arsenic contaminated water}

Several methods are available for the determination of arsenic in water by WHO and several studies have been conducted for arsenic removal (Kartinen and Martin, 1995; Joshi and Chaudhury, 1996; Gates, 1998; Leupin et al., 2005; Mondal et al., 2013; Sharma et al., 2005a; Sharma, 2007a, 2007b). The most common of these methods include:

(i) Atomic absorption spectroscopic method - (a) hydride generation atomic absorption (AAS - HG) and (b) electrothermal atomic absorption (AAS - GF).

(ii) Silver diethyldithiocarbamate method (SDDC). 
(iii) Inductively coupled plasma (ICP) method - (a) mass spectrometry (ICP-MS) and (b) atomic emission spectrometry (ICP-AES).

(iv) Anodic stripping voltammetry (ASV).

There are also several available options suited for arranging drinking water with low arsenic content such as:

(i) Explore alternative source of water with low arsenic content.

(ii) Treatment/removal of arsenic from the water source.

It is accepted that arsenic is found in shallow groundwater, while deep groundwater is either free of arsenic content or have low content. However, the depth to arsenic free aquifers differs between the locations so a detailed server is needed. The second option is to use surface water i.e lakes, rivers and ponds which are arsenic free or have a low arsenic content. The third option is to harvest rainwater, historically it is a way to utilize rainwater for domestic water supply and it has been used around the globe (BGS, 2004; Ahmed et al., 2005; WHO, 2011).

The aim of this section is to review and update the recent advances made in the technological development in arsenic removal technologies and to explore the potential of those advances so we can document the problem of arsenic contamination. There will be a special focus on the efficiency, applicability and social acceptability of the various technologies. In the 1990s, several methods were introduced for the removal of arsenic from water through large conventional treatment plants. The most commonly used technologies include adsorption onto sportive media, ion exchange resin and membrane processes, oxidation (biological and chemical), co-precipitation and adsorption onto coagulated flocs, lime treatment, and bacterial treatment, which can be applied for arsenic removal (Gates, 1998; Leupin et al., 2005; Sharma et al., 2005a; Sharma, 2007a, 2007b; Mondal et al., 2013) These techniques are still being used all around the world, several techniques are defined below.

\section{Arsenic removal by Oxidation}

Arsenic $[\mathrm{As}(\mathrm{III})$ and $\mathrm{As}(\mathrm{V})]$ is present in groundwater so oxidation is a pretreatment process which is conducted for converting arsenite to arsenate/AsIII, then to AsV and finally AsV precipitation is takes place. This process is important for anoxic/anaerobic groundwater because AsIII is the pre-dominant form of arsenic at aneutral $\mathrm{pH}$ (Sharma et al., 2007). Free chlorine, chlorine dioxide, hypochlorite, chloroamine, ferrate, ozone, oxygen, hydrogen peroxide, permanganate, and fulton's reagent are used for the oxidation of AsIII into AsV (Sharma et al., 2005b; Sharma and Sohn, 2009), but in developing countries, hypochloride, atmospheric oxygen and permanganate are being used. During the process of oxidation - which can take up to a couple of weeks hydrogen peroxide and chloroamine are slower than permanganate, chlorine and ozone (Islam, 2005, 2007). It is accepted that free Chlorine or hypochlorite is very effective for the oxidation of AsII, while theoxidation of AsIII is well achieved by ozone. However, chlorine dioxide is prohibited to use for surface water, American environmental agencies paymuch attention to this factor (Sarker, 2010). About the removalof arsenic, Utilizing FeO42- forpurifying water is recommended HFO (hydrous ferric oxide) appears to be the most important phase responsible for removing the arsenic from ground water around the world. It is well documented that High arsenic came into contact with iron oxides in the shallow aquifer, which could possibly lead to arsenic removal (Young, 1996; BGS, 2004; Ahmed et al., 2005; Lena et al., 2014; Shankar et al., 2014; Wegelin et al., 2000). Thus, for the removal of arsenic from water, 
oxidation/precipitation technology is very effective (Yoon and Lee, 2005; Sharma et al., 2005b).

\section{Arsenic removal by In-situ Oxidation}

DPHE Danida Arsenic Mitigation Pilot Project is applied for In-situ oxidation of iron and arsenic in the aquifer. Stored aerated tube-well water is released back into the aquifer. The dissolved oxygen in water oxidizes arsenite to arsenate (less mobile) and the ferrous iron in the aquifer is oxidized to ferric iron which leads to a reduction in arsenic content in tube-well water. Results of the experiment in-situ oxidation show that arsenic in tube-well water is reduced to about half due to underground-precipitation and adsorption on ferric iron. In-situ oxidation has also been achieved by pumping the oxygenated water into the groundwater aquifer to reduce the arsenic content in the pumped groundwater. While its potential for the removal of arsenic is only little, the results indicate that arsenic concentrations can be reduced in the groundwater zone before water extraction (Dutta et al., 2004; Sharma et al., 2007).

\section{Arsenic removal by Photochemical, Solar photo-catalytic Oxidation}

Photochemical and photo-catalytic oxidation of AsIII have been used in many studies for arsenic removal. The most widely tested chemical oxidant in presence of naturally occurring iron in the field is UV-light assisted oxidation of AsIII (Miller et al., 2011) because FeIII - hydr-oxide and chloride species can absorb photons to provide highly oxidizing hydr-oxyl and di-chloro radicals which converts AsIII to AsV (Ryu et al., 2013), as SORAS is a simple technique of solar oxidation for arsenic in transparent bottles to reduce arsenic content of drinking water (Emett and Khoe, 2001). It is also indicated that the efficient oxidation of AsIII to AsV can be achieved by photo-catalytic oxidation (PCO) (Bissen et al., 2001). Here ultraviolet radiations speedup the oxidation of AsIII in presence of other oxidants or oxygen. Ultraviolet radiation/solar light help to create/generate the hydroxyl-radicals via the the process of photolysis of $\mathrm{Fe}(\mathrm{III})$ i.e $(\mathrm{FeOH} 2+)$ and both oxygen and hydroxyle radicals accelerate the rate of oxidation.

It has also been investigated that adsorption of arsenic on $\mathrm{TiO} 2$ takes place while the oxidation process of AsIII to AsV is through photo-catalytic oxidation and $\mathrm{TiO} 2$. This can provide safe water; we know this because from experiments formentioned, it shows that it reduced arsenic levels to less than the standard limit given by WHO for drinkingwater (Anthony et al., 1990, 2000; McNeill and Edwards, 1995; Dutta et al., 2004, 2005; Choong et al., 2007; Ravenscroft, 2009). This experiment is still being used in Bangladesh and indicated that this process averagely can reduce one-third of arsenic content from water.

\section{Arsenic removal by Biological oxidation}

Study (Pallier et al., 2010) documented that some micro-organisms such as Gallionella ferruginea and Leptothrixochracea support and accelerate biotic-oxidation of iron. The study (Pallier et al., 2010) was conducted in the laboratory where iron-oxides and micro-organisms (Gallionella ferruginea and Leptothrixochracea) were deposited in a filter-medium, which has a favorable environment for the adsorption of arsenic, as AsIII cannot be efficiently absorbed onto iron-oxides. These micro-organisms are assigned to oxidize AsIII to AsV, which got adsorbed in FeIII. This leads to up-to 95\% removal of arsenic. Kinetics of bacterial oxidation of AsIII and oever all removal of 
AsV by sorption onto bio-genic manganese-oxides during ground-water treatment was also studied (Sharma et al., 2007; Pallier et al., 2010; Hu et al., 2012). Biological oxidation is a new technique of the oxidation of iron and manganese as a treatment technique for arsenic removal. These biological treatment techniques are the natural biological processes, and it takes a couple of days for remediation of metals in soil and groundwater by certain plants and micro-organisms. During treatment, the following sequences of reactions have taken place in the treatment system:

a. FeII to FeIII and MnII to MnIV (oxidation).

b. AsIII to AsV (oxidation).

c. $\mathrm{MnO}_{2}$ (Precipitation).

d. Abiotic-oxidation of AsIII by $\mathrm{MnO}_{2}$.

e. AsV sorption via $\mathrm{MnO}_{2}$.

Whereas steps (a) and (b) are biotic steps (c) to (e) are abiotic. This natural process for treatment has been found excellent as it can lead to up-to $95 \%$ of the removal of arsenic (Pallier et al., 2010).

\section{Arsenic removal by Coagulation-flocculation}

Coagulation-flocculation has got attention for the removal of arsenic from water, it is most commonly used for larger-capacity facilities and it requires the formation of a floc used to remove arsenic from groundwater. Coagulation-flocculation usually requires $\mathrm{Fe}$ and $\mathrm{Al}$ based coagulants among other various chemical coagulants i.e ferric chloride, or ferric sulfate or aluminium sulfate, need to be added and dissolved in water under efficient stirring for 1-10 minutes. Positive-charged cat-ionic coagulants have to decrease the negative charge of colloids. In this process, aggregation of particles forms larger particles. It is described that this technique obtained enough amount for removal, which roundedout to more than $90 \%$ of $\mathrm{AsV}$ and $77 \%$ of AsIII. While using $9.2 \mathrm{ppm}$ of $\mathrm{Fe} 3+$ aluminium or when ferric hydroxide micro-flocs are formed, As trivalent arsenic occurs in non-ionized form. For efficient removal, oxidation of As(III) to As(V) is thus required as a pretreatment. This surely can be achieved with the addition of bleaching powder (chlorine) or potassium permanganate. It has been documented that this technique is good for removal of arsenic below standard drinking water and also $\mathrm{Fe}$ based coagulants have also been investigated by several authors (Cheng et al., 1994; Appelo et al., 1999; Song et al., 2006; Sharma et al., 2007; Andrianisa et al., 2008; Gupta et al., 2009; Baskan and Pala, 2010; Lakshmanan et al., 2010; Van Halem et al., 2010; Lacasa et al., 2011). Recently, Hu et al. (2012) has used it and found the same.

Some of chemical coagulants are being used, whereas Fe based coagulants have been documented to be most efficient in water treatment than others e.g Al based coagulants (D.P.H.E, 2001; Katsoyiannis et al., 2004). For efficient removal of arsenic from water, the arsenic needs to be adsorbed on amorphous metal hydr-oxides formed from coagulant. There is critical limitation in the process of coagulation/flocculation, it produces a large amount of sludge along with a big concentration of arsenic (Hering et al., 1996; Appelo et al., 1999; D.P.H.E, 2001; Song et al., 2006; Sharma et al., 2007; Andrianisa et al., 2008; Gupta et al., 2009; Baskan and Pala, 2010; Lakshmanan et al., 2010; Van Halem et al., 2010; Lacasa et al., 2011). Real management of the contaminated sludge is needed for safeguarding the environment from secondary pollution and thus reduces the applicability of this method in field conditions. 


\section{Arsenic removal by Electro-coagulation}

Coagulation/flocculation has an alternative way known to be electro-coagulation which has a different the process, instead of adding a chemical reagent as ferricchloride; metallic cat-ions are directly generated in the effluent to be treated while applying current between iron electrodes for dissolving soluble anodes. Generally, Electrolytic-oxidation of a sacrificial iron anode creates FeIII oxy-hydroxides / precipitates in the arsenic contaminated water in electro-coagulation. While with FeIII precipitated arsenic produces bi-nuclear inner-sphere complexes and it further aggregates to form a floc. Then metallic cat-ions and hydroxides are formed and colloids neutralize negatively charged which allow them to coagulate and finally create helpful results (Ghurye et al., 2004; Katsoyiannis and Zouboulis, 2006a, 2006b).

\section{Arsenic removal by Electro-Chemical}

In this method, a small amount of electricity is needed to create rust in arsenic contaminated water. The rust binds to arsenic, settling and/or filtering. The rust can then remove from the water (Jain and Singh, 2012).

\section{Arsenic removal by Adsorption}

This is one of the processes of adsorption, in which, solid particles are used for removing substances from solutions such as gas or liquid. Removal of arsenic by this technique onto activated/coated surfaces has been famous and used the most in many countries. Some of its benefits are its low cost, high removal efficiency, easy operation and handling and also its sludge-free day-to-day operations. There is an extra advantage of this technology a number of the adsorbents can be reused and regenerated. Several studies have addressed the arsenic-removal by adsorption via many adsorbents (Wilkie and Hering, 1996; Mohan and Pittman, 2007), including commercial activated carbon, activated alumina, layered double hydroxide, natural/modified clays and zeolites. Mohan and Pittman (2007) and Wilkie and Hering (1996) have reviewed and addressed approximately 40 different types of adsorbents using published literature, with more than 500 references. Recently, gaps in exploration and improvement in new adsorbents are being found. A few years back adsorption based on zeolites (Raven et al., 1998), iron oxides (Grafe et al., 2001; Zhu et al., 2013), alumina (Kanematsu et al., 2013), clays (Swarnkar and Tomar, 2012), etc. to adsorb arsenic from water and the removal of arsenic by adsorption processes/techniques probably depended on $\mathrm{pH}$ and the speciation of arsenic with better AsV removals as compared to AsIII at a $\mathrm{pH}$ level lower than 7 (Giménez et al., 2010; Anjum et al., 2011; Sun et al., 2013; Han et al., 2013; Zhu et al., 2013). Several other studies such as Kanematsu et al. (2013) reviewed that the general rate of arsenic adsorption and capacity adsorbents further depend on the presence of other ions such as: silicate, phosphate, $\mathrm{HCO}-3$, and $\mathrm{Ca} 2+$. These ions compete for the adsorption sites; some other studies (Lin and Wu, 2001; Singh and Pant, 2004) also substantiated this fact. It is documented that the most widely tested aluminium-oxide is activated alumina (AA) (Giles et al., 2011; Genuchten et al., 2012; Kanematsu et al., 2013). There are some other adsorption methods used for removal of arsenic from water, which are discussed in the section below. 


\section{Arsenic removal by Bucket Treatment Unit}

The Techniques of Bucket Treatment Unit (B.T.U) is an extremely effective and affordable treatment technique for the removal of arsenic within the household. Locally available materials can be used to build the treatment unit and if operated properly and smoothly, it is effective for removing of arsenic from water. These technology units units are generally based on chemical doses of $2 \mathrm{mg} / \mathrm{L}$ of potassium permanganate and $200 \mathrm{mg} / \mathrm{L}$ aluminum sulfate in a crushed powder form. In both lab and field conditions, these units were documented to provide good performances in removing arsenic.

Bucket Treatment Unit (B.T.U) was proposed by the DPHE-Danida Project which is based on the principles of co- precipitation, coagulation and adsorption techniques/processes. In this technique, there are two buckets, each one has a 20 liter capacity, and are placed one above the other. The further the process is conducted; chemicals are put manually with arsenic contaminated water in the upper red bucket. Mixing of chemicals is done by vigorous stirring with a wooden stick for about 30 to 60 seconds, followed by the flocculation process by gentle stirring for about 90 second. It takes 1-2 hours to settle. Once the water is settles, the water from the top red bucket is further allowed to flow via plastic pipe into the lower the green bucket, where a filter is already installed. In the lower bucket, which should have sand filter and a valve sludge does not build up in the upper bucket. This is how practically a treated water container (EPA, 2000a, 2000b; Giles et al., 2011).

\section{Arsenic removal by Membrane technology (MT)}

Membrane technologies, i.e RO, have been documented as reliable and efficient for arsenic removal. RO has proven to be the best practiced technology which can completely purify water. It is generally accepted that $\mathrm{RO}$ is superior in both pilot-scale and lab experiments; results have shown more than 95\% As(V) and 74\% As(III) removal efficiencies (BAMWSP, 2001; Tripathy and Raichur, 2008). Membrane processes get rid of arsenic through electric repulsion, filtration, and adsorption of arsenic containing compounds. With the help of poly-sulfone thin film and nanofiltration membrane (BQ01), the distinction between the removal of As(III) and As(V) was explored (Sarkar et al., 2000). It has been observed that the elimination of As(V) was much higher than that of As(III). Furthermore, another study (Kohnhorst and Paul, 2000) was conducted on the nano-filtration operating conditions, it was concluded that there is no effect on arsenic removal by the trans-membrane pressure, temperature or cross-flow velocity (Kohnhorst and Paul, 2000). This technique is proven to be the best and results shows that up to $99 \%$ of the arsenic can be removed (Sheng et al., 2006; Xi et al., 2014) through the conducted studies.

\section{Arsenic removal by nano-filtration Technology}

Arsenic is being removed from groundwater by nano-filtration (NF) membrane configuration. It has played a key role in controlling operation performances and membrane fouling. The nano-filtration (NF) membrane surface puts negatively charged above its iso-electric point (approximately at $\mathrm{pH}$ 5.9-6.4). Generally, alkaline/neutral $\mathrm{pH}$ is adjusted for raw groundwater so it brings up the effect of electrical charge repulsion and ion removal efficiencies, which is improved by nano-filtration (NF). This nano-filtration (NF) system has an efficiency of up to $92 \sim 94 \%$ for arsenic removal (Xie et al., 2015; Song et al., 2015). 


\section{Arsenic removal by Activated alumina (AA)}

Activated alumina (AA) successfully removed arsenal from water supply systems and it was the first adsorptive medium for water supplies (Xie et al., 2008). Activated alumina is defined as a physical/chemical process, which is used particularly for the removal of arsenic and other ions. In this process, ions in feed water are sorbed to the oxidized Activated alumina (AA) surface. It is the widely tested aluminum oxide. It is prepared at high temperature, generally by the thermal de-hydration of aluminium hydroxide $\mathrm{Al}(\mathrm{OH}) 3$. It has diameter approximately $0.3-0.6 \mathrm{~mm}$; in addition, it has a high surface area for impressive sorption properties as it is a porous, granular material. The AA is used in the contaminants such as fluoride, arsenic NOM, silica and selenium. (Holl, 2010). It has been reported that, alum-impregnated AA can be adsorbent for AsV rather than untreated $\mathrm{AA}$ at a $\mathrm{pH}$ range of 2.8-11.5. When employed in batch mode, AsV concentration could be decreased down from $10 \mathrm{mgL}^{-1}(10,000 \mathrm{ppb})$ to $40 \mathrm{ppb}$ (Katsoyiannis and Zouboulis, 2006a, 2006b).

\section{Arsenic removal by Stevens Institute Technology}

In this technology, the process resembles the previously mentioned B.T.U as Bucket Treatment Unit (B.T.U) proposed by DPHE-Danida Project which is mostly based on the principles of co-precipitation, coagulation and adsorption techniques/processes. This technology is also involved in two buckets, the first bucket is to mix chemicals (such as calcium hypo-chloride and iron sulphate) then supply in packets. The other bucket is used to separate flocs, where two processes have taken place (a) sedimentation and (b) filtration. The second bucket has a second inner bucket with slits on the sides to help sedimentation and to keep the filter sand bed in place (EPA, 2000a). This technology has been mostly used in Bangladesh and has been effective. The results of tested samples show that 80 to $95 \%$ of the samples reduce arsenic concentration to less than $0.05 \mathrm{mg} / \mathrm{L}$ (EPA, 2000a, 2000b).

\section{Arsenic removal by iron coating}

An experimental study has been conducted (Seidel et al., 2001), where an iron coating method is used as a simple groundwater remediation technology, which has great potential. Moreover, it is affordable, especially in villages and rural areas where groundwater is used by communities for drinking purposes. Under different conditions, coated iron oxide/hydroxide was investigated for the arsenic removal mechanism using an electron probe microanalysis, scanning-electron microscopy(SEM)/X-ray absorption spectroscopy, and fourier transformation infrared spectroscopy. It has proven to be an effective method for arsenic removal. Generally, the 4-step develop aquifer iron coating method, alternating injection of oxidant, iron salt and oxygen-free water. In situ the removal of arsenic from ground water in an aquifer was achieved by simultaneous injections of $\mathrm{As}(\mathrm{V})$ and $\mathrm{Fe}(\mathrm{II})$ reagents. The technique of adsorption or co-precipitation brings arsenic fixation with fine particles of goethite by way of bi-dentate bi-nuclear complexes. Therefore, the study documents that the technology results in high arsenic removal efficiency by the situ aquifer iron coating technique. This is likely resulted by the expanded particular surface area of the small goethite particles, which enhanced arsenic sorption capability and/or from coprecipitation of arsenic on the surface of goethite particles. 


\section{Arsenic removal by hollow fiber nano-filtration membranes with a sulfo-nated poly ether ether ketone coating}

In 2015, this technique got high attention when experimental studies were done (Saitua et al., 2005). The overall performance of this technique for arsenic removal from drinking water was tested. The membrane works well and does not allow above $95 \%$ of $\mathrm{As}(\mathrm{V})$ to contaminate the water. Furthermore, the membrane properties were studied, and rejects arsenic in the presence of interfering ions. Results indicated that di-electric exclusion might be able to rationally explain the rejection deviation from the Donnan exclusion effect. The valence of the ions played a major role, where there was a presence of interfering ions. Finally, cost estimation was conducted at $1000 \mathrm{~m} 3 \mathrm{~h}^{-1}$, which is about 0.15 US\$ per $3 \mathrm{~m}$ when using the proposed SPEEK coated hollow fiber membrane for a plant. Results from different sources indicate that a SPEEK composite nano-filtration membrane is mostly suitable and efficient for removing arsenic from groundwater (Pinon-Miramontes et al., 2003; Saitua et al., 2005; Shih, 2005; Harisha et al., 2010).

\section{Arsenic removal by Naturally Occurring Iron}

This method has been found effective in Asian countries, where naturally occurring iron is used to precipitate the ground water and for removing arsenic by adsorption (Ahmed, 2001).

\section{Concluding Remarks and future perspective}

Arsenic is worldwide problem; arsenic has been documented in the Americas, Africa, Asia, Europe and Pacific countries. Arsenic in groundwater can found in several geographical regions in mainland China. Studies identify areas of high-risk arsenic contamination in the north of China, including Xinjiang, Shanxi, Inner Mongolia, Henan, Shandong and Jiangsu. The most affected areas to date, rounded about 3998 individuals with arsenicosis, including children, with most living in rural areas of the Shanxi province, in northern China.

Arsenic has created health problems around the world. The major arsenicosis regions are presently documented in large deltas and along biggest rivers merging from the Himalayas, such as in the Bengal delta, other parts of India, Nepal, Pakistan, Myanmar, Vietnam, Cambodia and China. Usually, arsenic enters human-beings through two pathways; first, direct consumption of drinking water contaminated by arsenic and second, for populations not exposed to elevated arsenic in drinking water, the indirect intake through foods and crops cultivated using arsenic-contaminated water represent the main sources of arsenic intake for humans.

Several available options suited for arranging drinking water with low arsenic content such as: (i) Explore alternative source of water with low arsenic content and (ii) Treatment/removal of arsenic from the water source. The most commonly used technologies include adsorption onto sorptive media, ion exchange resin and membrane processes, oxidation (biological and chemical), co-precipitation and adsorption onto coagulated flocs, lime treatment, and bacterial treatment, which can all be applied for arsenic removal.

Aeration/Fe precipitation/filtration is developed to remove arsenic; this technology has been accepted in China. The modification of commercial adsorbents (e.g., activated 
carbon and activated alumina) and modification of natural mineral materials (e.g., zeolites) seem to be an approach to lower the operating cost and improve arsenic removal efficiency. Recently, several technologies to remove arsenic from drinking water have been introduced. Many of them are described in this review; each have their own advantages and disadvantages. Most of these technologies for removal of arsenic involve the direct removal of $\mathrm{AsV}$ or converting AsIII to AsV followed by removal of AsV.

While talking about future perspective, the government should monitor and document industrial and agricultural activities as they brought the arsenic pollution issue to the bodies of water in the first place.

Mining or chemical plants should be documented to deal with sewage, sludge storage and waste treatment. Sub departments should be developed and should be supervised by well-known persons; there should also be sampling and analysis of the discharge from industrial plants, which aim to supply safe drinking water to people in rural areas, including arsenic control. The government should take additional should take steps and put restrictions, if there is a not safe water source. Investment should be employed on the great engineering system for water transportation and water quality should be well documented. Small treatment facilities installations should be recommended in rural areas.

Acknowledgements. This research was supported by the Fuling Shale Gas Environmental Exploration Technology of National Science and Technology Special Project (grant no.: 2016ZX05060), the Demonstration of Integrated Management of Rocky Desertification and Enhancement of Ecological Service Function in Karst Peak-cluster Depression (grant no.:2016YFC0502400).

\section{REFERENCES}

[1] Ahmad, S. A., Gulzar, A., Rehman, H. U. (2013): Study of Arsenic in drinking water of distric Kasur Pakistan. - Journal of World Applied Science 24(5): 634-640.

[2] Ahmed, M. F. (2001): An Overview of Arsenic Removal Technologies in Bangladesh and India. - In: Ahmed, M. F., Ali, M. A., Adeel, Z. (eds.) Technologies for Arsenic Removal from Drinking Water. Bangladesh University of Engineering \& Technology (BUET) and United Nations University (UNU), May: 251-269.

[3] Ahmed, M. F., Shamsuddin, S. A. J., Mahmud, S. G., Rashid, H., Deere, D., Howard, G. (2005): Risk Assessment of Arsenic Mitigation Options (RAAMO). - APSU, Dhaka, Bangladesh.

[4] Andrianisa, H. A., Ito, A., Sasaki, A., Aizawa, J., Umita, T. (2008): Biotransformation of arsenic species by activated sludge and removal of bio-oxidised arsenate from wastewater by coagulation with ferric chloride. - Water Research 42(19): 4809-4817.

[5] Anjum, A., Lokeswari, P., Kaur, M., Datta, M. (2011): Removal ofAs(III) from aqueous solutions using montmorillonite. - J.Anal.Sci.MethodsInstrum. 1: 25-30.

[6] Anthony, J. W., Bideaux, R. A., Bladh, K. W., Nichols, M. C. (1990): Handbook of Mineralogy, vol I. Elements, Sulfides, Sulfosalts. - Mineral Data Publishing, Tucson, AZ.

[7] Anthony, J. W., Bideaux, R. A., Bladh, K. W., Nichols, M. C. (2000): Handbook of Mineralogy, vol IV. Arsenates, Phosphates, Vanadates. - Mineral Data Publishing, Tuscon, AZ. 
[8] Appelo, C. A. J., Drijver, B., Hekkenberg, R., deJonge, M. (1999): Modeling in situiron removal from ground water. - Groundwater 37: 811-817.

[9] BAMWSP, DFID and Water Aid Bangladesh (2001): Rapid Assessment of Household Level Arsenic Removal Technologies, Phase 1 and Phase-II. - Final Report, WS Atkins International Limited.

[10] Baskan, M. B., Pala, A. (2010): A statistical experiment design approach for arsenic removal by coagulation process using aluminum sulfate. - Desalination 254(1-3): 42-48.

[11] Berg, M., Luzi, S., Trang, P .T .K., Viet, P. H., Giger, W., Stuben, D. (2006): Arsenic removal from groundwater by household sand filters: Comparative field study, model calculations, and health benefits. - Environ. Sci. Technol. 40: 5567-5573.

[12] Berg, M., Stengel, C., Trang, P. T. K., Viet, P. H., Sampson, M. L., Leng, M., Samreth, S., Fredericks, D. (2007): Magnitude of arsenic pollution in the Mekong and Red River Deltas-Cambodia and Vietnam. - Sci.Total Environ. 372: 413-425.

[13] BGS. (2004): DPHE/BGS National Hydro chemical Survey. - Available on: Bangladesh/mapsnhs.html.

[14] Bian, J. M., Tang, J., Zhang, L. S., Ma, H. Y., Zhao, J. (2012): Arsenic distribution and geological factors in the western Jilin province, China. - J. Geochem. Explor. 112: 347356.

[15] Bissen, M., V-Baron, M. M., Schindelin, A. J., Frimmel, F. H. (2001): TiO2-catalyzed photo oxidation of arsenite to arsenate in aqueous samples. - Chemosphere 44: 751-757.

[16] Bo, Y., Luo, L. Q. (2010): Distribution characteristics of arsenic in environment of Bayannaoer, Inner Mongolia. - J. Environ. Health. 27: 696-699. (in Chinese with English abstract).

[17] Brammer, H. (2008): Threat of arsenic of agriculture in India, Bangladesh and Nepal. Econ. Polit.Week 43: 79-84.

[18] Chakraborti, D., Rahman, M. M., Das, B., Murrill, M., Dey, S., Mukherjee, S. C., Dhar, R. K., Biswas, B. K., Chowdhury, U. K., Roy, S., Sorif, S., Selim, M., Rahman, M., Quamruzzaman, Q. (2010): Status of ground water arsenic contaminationin Bangladesh: a14-year study report. - Water Res. 44: 5789-5802.

[19] Chan, E., Griffiths, S. (2010): The implication of water on public health: the case of China. - Perspect. Public Health 130: 209-210.

[20] Chen, H. F., Yan, M., Yang, X. F., Chen, Z., Wang, G. G., Schmidt-Vogt, D., Xu, Y. F., $\mathrm{Xu}$, J. C. (2012): Spatial distribution and temporal variation of high fluoride contents in groundwater and prevalence of fluorosis in humans in Yuanmou County, Southwest China. - J. Hazard. Mater. 235: 201-209.

[21] Chen, Y. C., Su, H. J., Guo, Y. L., Hsueh, Y. M., Smith, T. J., Ryan, L. M., Lee, M. S., Christiani, D. C. (2003): Arsenic methylation and bladder cancer risk in Taiwan. - Cancer Causes Control 1: 303-310.

[22] Cheng, C. R., Liang, S., Wang, H. C., Beuhler, M. D. (1994): Enhanced coagulation for arsenic removal. - J. American Water Works Association 86(9): 79-90.

[23] Cheng, Z., van Geen, A., Jiang, C., Meng, X., Seddique, A., Ahmed, K. M. (2004): Performance of a household-level arsenic removal system during 4-month deployments in Bangladesh. - Environ. Sci. Technol. 38: 3442-3448.

[24] China water risk (2013): Reports. - Available at:http://www. chinawaterrisk.org/notices/groundwater-arsenic-contamination-in-china/.

[25] Choong, T. S. Y., Chuah, T. G., Robiah, Y., Gregory Koay, F. L., Azni, I. (2007): Arsenic toxicity, health hazards and removal techniques from water: an overview. Desalination 217(1-3): 139-166.

[26] Deng, B., Yang, X. J., Deng, J. Y., Li, D. Y., Zhou, D. Y., Zhu, L., Zhang, L. L., Wang, G. Q., Liao, B., Ying, S. X. (2004): Epidemiological investigation on drinking water type of arsenicosis in Jinchuan County of Sichuan Province. - J. Prev. Med. Inf. 20: 370-372. (in Chinese). 
[27] Deng, Y., Wang, Y., Ma, T. (2009): Speciation and enrichment of arsenic. - Appl. Geochem. 24: 587-599.

[28] D.P.H.E. (2001): DPHE-Danida Arsenic Mitigation Pilot Project. - June28, 2001. Available on: (http:// phys4.harvard.edu/wwilson/2bucket.html).

[29] Dutta, P. K., Ray, A. K., Sharma, V. K., Millero, F. J. (2004): Adsorption of arsenate and arsenite on titanium dioxide suspensions. - J.Colloid.InterfaceSci. 278: 270-275.

[30] Dutta, P. K., Pehkonen, S. O., Sharma, V. K., Ray, A. K. (2005): Photocatalytic oxidation of arsenic (III): evidence of hydroxyl radicals. - Environ.Sci.Technol. 39: 1827-1834.

[31] Emett, M. T., Khoe, G. H. (2001): Photochemical oxidation of arsenic by oxygen and iron in acidic solutions. - WaterRes. 35: 649-656.

[32] Engel, R. R., Smith, A. H. (2004): Arsenic in drinking water and mortality from vascular disease: an ecologic analysis in 30 countries in the United States. - Archives of Environmental Health 49(5): 418-427.

[33] EPA. (2000a): Technologies and Costs for Removal of Arsenic from Drinking Water. U. S. EPA, EPA815R00028, Prepared by Malcolm Pirnie, Inc. under contract 68C60039 for EPAORD, December 2000. Available online: http://www.epa.gov/safewater/ars/ treatments_and_costs.pdf.

[34] EPA. (2000b): Regulations on the Disposal of Arsenic Residuals from Drinking Water Treatment Plants. - Office of Research and Development, U.S.EPA, EPA/600/R-00/ 025. May 2000. Available online: http://www.epa.gov/ORD/WebPubs/residuals/index.htm.

[35] Fendorf, S., Nico, P. S., Kocar, B. D., Tufano, K. J. (2010a): Arsenic chemistry in soils and sediments. - California Digital Library University of California.

[36] Fendorf, S., Michael, H. A., vanGeen, A. (2010b): Spatial and temporal variations of ground-water arsenic in South and South east Asia. - Science 328: 1123-1127.

[37] Ferlay, J., Soerjomataram, I., Dikshit, R., Eser, S., Mathers, C., Rebelo, M., Parkin, D. M., Forman, D., Bray, F. (2015): Cancer incidence and mortality worldwide: sources, methods and major patterns in GLOBOCAN 2012. - Int. J. Cancer 136(5):E359-86. DOI: 10.1002/ijc.29210.

[38] Fontcuberta, M., Calderon, J., Villalbí, J. R., Centrich, F., Portaña, S., Espelt, A., Duran, J., Nebot, M. (2011): Total and inorganic arsenic in marketed food and associated health risks for the Catalan (Spain) population. - J.Agric.FoodChem. 59: 10013-10022.

[39] Gao, X., Su, C., Wang, Y., Hu, Q. (2013): Mobility of arsenic in aquifer sediments at Datong Basin, northern China: effect of bicarbonate and phosphate. - J. Geochem. Explor. (special issue) 135: 93-103.

[40] Gates, D. (1998): The Chlorine Dioxide Handbook. - American Water Works Association, Denver, CO.

[41] Genuchten, C. M., Addy, S. E. A., Peña, J., Gadgil, A. J. (2012): Removing arsenic fro synthetic groundwater with iron electrocoagulation: an Fe and AsK-edge EXAFS study.Environ.Sci.Technol. 46: 986-994.

[42] Ghurye, G., Clifford, D., Tripp, A. (2004): Iron coagulation and direct microfiltration to remove arsenic from ground water. - J.Am.WaterWorksAssoc. 96: 143-152.

[43] Giles, D. E., Mohapatra, M., Issa, T. B., Anand, S., Singh, P. (2011): Iron and aluminium based adsorption strategies for removing arsenic from water. - Journal of Environmental Management 92(12): 3011-3022.

[44] Giménez, J., dePablo, J., Martínez, M., Rovira, M., Valderrama, C. (2010): Reactive transport of arsenic(III) and arsenic(V) on natural hematite: experimental and modeling. J. Colloid Interface Sci. 348: 293-297.

[45] Grafe, M., Eick, M. J., Grossl, P. R. (2001): Adsorption of arsenate (V) and arsenite (III) on goethite in the presence and absence of dissolved organic carbon. - Soil Science Society of America Journal 65(6): 1680-1687.

[46] Guo, X. J., Fujino, Y., Chai, J. S., Wu, K. G., Xia, Y. J., Li, Y. H., Lv, J. A., Sun, Z. M., Yoshimura, T. (2003): The prevalence of subjective symptoms after exposure to arsenic in drinking water in Inner Mongolia, China. - J. Epidemiol. 13: 211-215. 
[47] Guo, H., Wang, Y. (2005): Geochemical characteristics of shallow groundwater in Datong basin, northwestern China. - Journal of Geochemical Exploration 87(3): 109-120.

[48] Guo, H. M., Tang, X. H., Yang, S. Z., Shen, Z. L. (2008): Effect of indigenous bacteria on geochemical behavior of arsenic in aquifer sediments from the Hetao Basin, Inner Mongolia: evidence from sediment incubations. - Appl. Geochem. 23: 3267-3277.

[49] Guo, H., Zhang, B., Wang, G., Shen, Z. (2010): Geochemical controls on arsenic and rare earth. - Chem. Geol. 270: 117-125.

[50] Guo, H., Wen, D., Liu, Z., Jia, Y., Guo, Q. (2013): A review of high arsenic groundwater in Mainland and Taiwan, China: Distribution, characteristics and geochemical processes. - Applied Geochemistry 41: 196-217.

[51] Hagiwara, H., Akai, J., Terasaki, K., Yoshimura, T., Luo, H. (2011): Black colored sandy sediments caused by bacterial action, and the mechanism for arsenic enrichment of groundwater in Inner Mongolia. - Applied Geochemistry 26: 380-393.

[52] Han, F. A., Hu, Y., Chen, L. S., Lu, R. Z., Jiang, Z. F., Yang, S. (2009): Influence factors of drinking water quality of rural areas in Huaihe and Yangtze Region in Jiangsu Province. - J. Environ. Health 26: 328-330. (in Chinese).

[53] Han, S.-B., Zhang, F.-C., Zhan, H., Jia, X.-F., He, J., Li, X.-F. (2010): An analysis of distribution and formation of high arsenic groundwater in northern China. - Geol. China 37: 745-753. (in Chinese with English abstract).

[54] Han, C., Li, H., Pu, H., Yu, H., Deng, L., Huang, S., Luo, Y. (2013): Synthesis and characterization of mesoporous alumina and their performances for removing arsenic $(\mathrm{V})$. - Chem. Eng.J. 217: 1-9.

[55] Hao, J., Xing, Z. F. (2010): Study on endemic of fluorosis and arsenism of Heilongjiang Province. - Chin. J. Public Health Manag. 26: $422-423$ (in Chinese).

[56] Harisha, R. S., Hosamani, K. M., Keri, R. S., Natarajm, S. K., Aminabhavi, T. M. (2010): Arsenic removal from drinking water using thin film composite nanofiltration membrane. - Desalination 252(1-3): 75-80.

[57] He, X., Teng, M., Wang, Y. X., Deng, Y. M., Huang, B., He, J., Zhao, J., Tian, C. Y., Li, Z. L. (2010): Geochemical characteristics of the As-bearing aquifer in the Hetao plain, Inner Mongolia. - Geol. China. 37: 781-788. (in Chinese with English abstract).

[58] He, J., Charlet, L. (2013): A review of arsenic presence in China drinking water. - J. Hydrol. 492: 79-88.

[59] Hering, J. G., Chen, P. Y., Wilkie, J. A., Elimelech, M., Liang, S. (1996): Arsenic removal by ferric chloride. - J. American Water Works Association 88(4): 155-167.

[60] Hering, J. G., Chen, P., Wilkie, J. A., Elimelech, M. (1997): Arsenic removal from drinking water during coagulation. - J. Env. Eng., ASCE 123(8): 800-807.

[61] Holl, W. H. (2010): Mechanisms of arsenic removal from water. - Environ. Geochem. Health 32: 287-290.

[62] Horner, N., Beauchemin, D. (2013): The effect of cooking and washing rice on the bioaccessibility of $\mathrm{As}, \mathrm{Cu}, \mathrm{Fe}, \mathrm{V}$ and $\mathrm{Zn}$ using an on-line continuous leaching method. AnalyticaChimicaActa 758: 28-35.

[63] Hsueh, Y. M., Cheng, G. S., Wu, M. M., Yu, H. S., Kuo, T. L., Chen, C. J. (1995): Multiple risk factors associated with arsenic-induced skin cancer: effects of chronic liver disease and male nutritional status. - Br.J.Cancer 71: 109-114.

[64] Hu, C., Liu, H., Chen, G., Qu, J. (2012): Effect of aluminum speciation on arsenic removal during coagulation process. - Separation and Purification Technology 86: 35-40.

[65] Huang, Y. Z., Qian, X. C., Wang, G. Q., Xiao, B. Y., Ren, D. D., Feng, Z. Y., Wu, J. Y., Xu, R. J., Zhang, F. E. (1985): Endemic chronic arsenism in Xinjiang. - Chin. Med. J. (Engl.) 98: 219-222.

[66] Huang, G. X., Sun, J. C., Ji, J. H., Zhang, E. X., Liu, J. T., Wang, J. C., Xiang, X. P., Chen, X., Cui, H. W. (2010): Distribution of arsenic in water and soil in the representative area of the Pearl River Delta. - Acta Sci. Nat. Univ. Sunyatsen. 49: 131137. 
[67] Huang, G., Chen, Z., Sun, J. (2014): Arsenic distribution and hydrochemical factors in urban groundwater, Foshan City, South China. - Chin.J.Geochem 33: 398-403. DOI: 10.1007/s11631-014-0704-0.

[68] IWR. (2011): 190-million-chinese-drinking-polluted-water. - Available on: http://www.indiawaterreview.in/Story/International/190-million-chinese-drinkingpolluted-water/148/18\#.XByZSx8anIU.

[69] Jain, C. K., Singh, R. D. (2012): Technological options for the removal of arsenic with special reference to South East Asia. - J. Environ. Manage. 107: 1-18.

[70] Jiang, J. Q. (2001): Removing arsenic from groundwater for the developing world--a review. - Water Sci Technol. 44(6): 89-98.

[71] Jiang, Y., Li, Y., Zhou, X., Jia, J., Zhou, Q., Li, Y. (2010): Distribution characteristics of high content fluorine and arsenic of groundwater and countermeasure in Huzhou areas of Zhejiang Province. - Resour. Surv. Environ. 31: 120-126. (in Chinese).

[72] Jin, Y., Liang, C., He, G., Cao, J. (2003): Study on distribution of endemic arsenism in China. - Wei Sheng Yan Jiu 32: 519-540.

[73] Joshi, A., Chaudhury, M. (1996): Removal of arsenic from groundwater by iron-oxidecoated sand. - ASCE Journal of Environmental Engineering 122(8): 769-771.

[74] Kanematsu, M., Young, T. M., Fukushi, K., Green, P. G., Darby, J. L. (2013): Arsenic(III, V) adsorption on a goethite-based adsorbent in the presence of major coexisting ions: modeling competitive adsorption consistent with spectroscopic and molecular evidence. - Geochimica et CosmochimicaActa. 106: 404-428.

[75] Kartinen, E. O., Martin, C. J. (1995): An overview of arsenic removal processes. - J. Desalination 103: 79-88.

[76] Katsoyiannis, I. A., Zouboulis, A. I. (2006a): Use of iron- and manganese-oxidizing bacteria for the combined removal of iron, manganese and arsenic from contaminated ground water. - WaterQual.Res.J.Can. 41: 117-129.

[77] Katsoyiannis, I. A., Zouboulis, A. I. (2006b): Comparative evaluation of conventional and alternative methods for the removal of arsenic from contaminated groundwaters. Rev. Environ. Health 21(1): 25-41.

[78] Katsoyiannis, I. A., Zouboulis, A. I., Jekel, M. (2004): Kinetics of bacterial As(III ) oxidation and subsequent $\mathrm{As}(\mathrm{V})$ removal by sorption onto biogenic manganese oxides during ground water treatment. - Ind.Eng.Chem.Res. 43: 486-493.

[79] Kohnhorst, A., Paul, P. (2000): Testing simple arsenic removal methods. - Water, Sanitation and Hygiene: Challenges of the Millennium, Pre-prints of the 26 WEDC Conference, Dhaka, Bangladesh: 177-181.

[80] Kongkea, P., Sthiannopkao, S., Kim, K.W., Wong, M. H., Sao, V., Hashim, J. H., Yasin, M., Salleh, M., Syed Mohamed, A. (2010): Health risk assessment of inorganic arsenic intake of Cambodia residents through ground water drinking path way. - Water Res. 44: 5777-5788.

[81] Lacasa, E., Cãnizares, P., S'aez, C., Fern'andez, F. J., Rodrigo, M. A. (2011): Removal of arsenic by iron and aluminium electrochemically assisted coagulation. - Separation and Purification Technology 79(1): 15-19.

[82] Lakshmanan, D., Clifford, D. A., Samanta, G. (2010): Comparative study of arsenic removal by iron using electrocoagulation and chemical coagulation. - Water Research 44(19): 5641-5652.

[83] Lee, J. J., Jang, C. S., Liu, C. W., Liang, C. P., Wang, S. W. (2009): Determining the probability of arsenic in groundwater using a parsimonious model. - Environ. Sci. Tech. 43: 6662-6668.

[84] Lena, Q. M., Hong-Jie, S., Bala, R., Bing, W, Jun, L., Li-Ping, P. (2014): Arsenic and selenium toxicity and their interactive effects in humans. - Environment International 69: $148-158$. 
[85] Leupin, O. X., Hug, S. J., Badruzzaman, A. B. M. (2005): Arsenic removal from Bangladesh tube well water with filter columns containing zero-valentiron filings and sand. - Environ. Sci. Technol. 39: 8032-8037.

[86] Li, W. D., Zou, Z., Zhao, L. S., Zhang, J. Q., Wang, X. C., Wang, Y. D. (2006): A water quality survey of endemic arsenicosis area in Anhui Province. - Anhui J. Prev. Med. 12: 193-196. (in Chinese with English abstract).

[87] Li, X. H., Hou, G. Q., Yuan, C. S., Liu, Y., Zhang, L., Yu, B., Cui, L. Q. (2010): Research on relationship between the concentration of water fluoride, water As and depth of well in the water-drinking endemic fluorosis areas of Qixian. - Henan. J. Prev. Med. 21: 133-134.

[88] Lin, T.-F., Wu, J.-K. (2001): Adsorption of arsenite and arsenate within activated alumina grains: equilibrium and kinetics. - Water Research 35(8): 2049-2057.

[89] Liu, J., Li, G. M., Liu, W. Y., Lin, S. G., Liu, W., Zhao, W. G., Zheng, Z. X., Qi, Y. J. (2003): Analysis of endemic arsenism distribution in Liaoning Province. - Chin. J. Endemiology 22: 258-259. (in Chinese).

[90] Liu, H., Zhang, G. P., Jin, Z. S., Liu, C. Q., Han, G. L., Li, L. (2009): Geochemical characteristics of geothermal fluid in Tengchong Area, Yunnan Province, China. - Acta Mineral. Sin. 29: 496-501. (in Chinese).

[91] Liu, F., Huang, G., Sun, J., Jing, J., Zhang, Y. (2014): Distribution of arsenic in shallow aquifers of Guangzhou region, China: natural and anthropogenic impacts. - Water Quality Research Journal of Canada, DOI: 10.2166/wqrjc.2014.014.

[92] Luo, Z.-D. (1993): Epidemiological survey on chronic arsenic poisoning in Inner Mongolia. - J. Endem. Dis. Inner Mong. 18: 4-6.

[93] Luo, Y. L., Jiang, P. A., Yu, Y. H., Zheng, C. X., Wu, H. Q., Zhang, G. B. (2006): Investigation and assessment on arsenic pollution of soil and groundwater in Kuitu. No.123 State Far. Arid Land Geogr. 29: 705-709.

[94] Maharjan, M., Watanabe, C., Ahmad, S. A., Ohtsuka, R. (2005): Arsenic contamination in drinking water and skin manifestations in low 1 and Nepal: the first community-based survey. - Am.J.Trop.Med.Hyg. 73: 477-479.

[95] Maity, J. P., Nath, B., Kar, S., Chen, C. Y., Banerjee, S., Jean, J. S., Liu, M. Y., Centeno, J. A., Bhattacharya, P., Chang, C. L., Santra, S. C. (2012): Arsenic induced health crisis in peri-urban Moyna and Ardebok villages, West Bengal, India: an exposure assessment study. - Environ.Geochem.Health. 34: 563-574.

[96] Malik, A. H., Khan, Z. M., Mahmood, Q., Nasreen, S., Bhatti, Z. A. (2009): Perspectives of low cost arsenic remediation of drinking water in Pakistan and other countries. $-\mathrm{J}$. Hazard.Mater. 168: 1-12.

[97] Mandal, B. K., Roy Chowdhury, T., Samanta, G., Basu, G. K., Chowdhury, P. P., Chanda, C. R., Lodh, D. (1996): Arsenic in ground water in seven districts of West Bengal, India-the biggest arsenic calamity in theworld. - Curr.Sci. 70: 976-985.

[98] Marchiset-Ferlay, N., Savanovitch, C., Sauvant-Rochat, M.-P. (2012): What is the best biomarker to assess arsenic exposure via drinking water? - Environ. Inter. 39: 150-171.

[99] McClintock, T. R., Chen, Y., Bundschuh, J., Oliver, J. T., Navoni, J., Olmos, V., Lepori, E. V., Ahsan, H., Parvez, F. (2012): Arsenic exposure in Latin America: Biomarkers, risk assessments and related health effects. - Sci. Total Environ. 429: 76-91.

[100] McNeill, L. S., Edwards, M. (1995): Soluble arsenic removal Atwater treatment plants. Journal of AmericanWaterWorks Association 87(4): 105-113.

[101] Miller, S. M., Spaulding, M. L., Zimmerman, J. B. (2011): Optimization of capacity and kinetics for a novel bio-based arsenic sorbent, TiO2-impregnated chitosan bead. - Water Research: 5745-5754.

[102] Mohan, D., Pittman, C. U. (2007): Arsenic removal from water/wastewater using adsorbents-A critical review. - J. Hazard. Mater. 142: 1-53. 
[103] Mondal, P., Bhowmick, S., Chatterjee, D., Figoli Vander Bruggen, B. (2013): Remediation of inorganic arsenic in ground water for safe water supply: acritical assessment of technological solutions. - Chemosphere 92: 157-170.

[104] Nickson, R. T., McArthur, J. M., Burgess, W. G., Ahmed, K. H., Ravenscroft, P., Rahman, M. (1998): Arsenic poisoning of Bangladesh groundwater. - Nature 395: 338.

[105] Nickson, R. T., McArthur, J. M., Ravenscroft, P., Burgess, W. G., Ahmed, K. M. (2000): Mechanism of arsenic release to groundwater, Bangladesh and West Bengal. - Appl. Geochem. 15: 403-413.

[106] Niedzielski, P., Siepak, J., Siepak, M. (2001): Total contents of arsenic, antimony and selenium in groundwater samples from Western Poland. - Pol. J. Environ. Stud. 10(5): 347.

[107] Oguri, T., Yoshinaga, J., Tao, H., Nakazato, T. (2014): Inorganic Arsenic in the Japanese Diet: Daily Intake and Source. - Archives of Environmental Contamination and Toxicology 66: 100-112.

[108] Pallier, V., Feuillade-Cathalifaud, G., Serpaud, B., Bollinger, J.-C. (2010): Effect of organic matter on arsenic removal during coagulation/flocculation treatment. - Journal of Colloid and Interface Science 342(1): 26-32.

[109] Pang, X. H., Shi, Y., Hao, L. Y., Du, H., Liu, L. P. (2003): Study on endemic arsenism distribution in Beijing. - China J. Public Health. 19: 976-977. (in Chinese).

[110] Pei, H., Liang, S., Ning, L. (2005): A discussion of the enrichment and formation of As in groundwater in Datong Basin. - Hydrogeol. Eng. Geol. 32: 65-69.

[111] Pinon-Miramontes, M., Bautista-Margulis, R. G., Perez-Hernandez, A. (2003): Removal of arsenic and fluoride from drinking water with cake alum and a polymeric anionic flocculent. - Fluoride 36(2): 122-128. (Research Report).

[112] Polya, D. A., Berg, M., Gault, A. G., Takahashi, Y. (2008): Arsenic in ground watersof South-East Asia: with emphasison Cambodia and Vietnam. - Appl.Geochem. 23: 29682976.

[113] Qin, X., Xu, G. Q. (2010): Distribution and effect factors of shallow groundwater As in Fuyang Region. - Ground Water 32: 44-45. (in Chinese).

[114] Qurat-ul-Ain, Farooqi, A., Sultana, J., Masood, N. (2017): Arsenic and fluoride cocontamination in shallow aquifers from agricultural suburbs and an industrial area of Punjab, Pakistan: Spatial trends, sources and human health implications. - DOI: 10.1177/0748233717706802 journals.sagepub.com/home/tih.

[115] Raven, K. P., Jain, A., Loeppert, R. H. (1998): Arsenite and arsenate adsorption on ferrihydrite: kinetics, equilibrium, and adsorption envelopes. - Environmental Science and Technology 32(3): 344-349.

[116] Rodríguez-Lado, L., Sun, G., Berg, M., Zhang, Q., Xue, H., Zheng, Q., Johnson, C. A. (2013): Groundwater Arsenic Contamination Throughout China. - Science 341(6148): 866-868. DOI: $10.1126 /$ science.1237484.

[117] Ryu, J., Monllor-Satoca, D., Kim, D. H., Yeo, J., Choi, W. (2013): Photo oxidation of arsenite under $254 \mathrm{nmir}$ radiation with aquantum yield higher than unity. Environ.Sci.Technol. 47: 9381-9387.

[118] Saha, D. (2009): Arsenic ground water contamination in parts of middle Gangaplain, Bihar. - Curr.Sci. 97: 753-755.

[119] Saitua, H., Campderros, M., Cerutti, S., Padilla, A. P. (2005): Effect of operating conditions in removal of arsenic from water by nanofiltration membrane. - Desalination 172: 173-180.

[120] Sanjrani, M. A., Mek, T., Sanjrani, N. D., Leghari, S. J., Moryani, H. T., Shabnam, A. B. (2017): Current Situation of Aqueous Arsenic Contamination in Pakistan, Focused on Sindh and Punjab Province, Pakistan: A Review. - J Pollut Eff Cont 5:4. doi:10.4176/2375-4397.1000207.

[121] Sanjrani, M. A., Talpur, H. A., Talpur, S. A. (2018): Physio-Chemical assessment of water sources for drinking purpose in Badin City, Sindh Province, Pakistan, (Water 
Supply Schemes and Hand Pumps). - Advance Research Journal of Multidisciplinary Discoveries 29(7): 38-44.

[122] Sarkar, A., Choudhury, T., Rahaman, A. (2000): Bucket Treatment unit for arsenic removal. - Water, Sanitation and Hygiene: Challenges of the Millennium, Pre-prints of the 26 WEDC Conference, Dhaka, Bangladesh.: 308-310.

[123] Sarkar, S., Greenleaf, J. E., Gupta, A., Ghosh, D., Blaney, L. M., Bandyopadhyay, P., Biswas, R. K., Dutta, A. K., Sengupta, A. K. (2010): Evolution of community-based arsenic removal systems in remote villages in West Bengal, India: Assessment of decadelong operation. - Water Res. 44: 5813-5822.

[124] Sarker, M. M. R. (2010): Determinants of Arsenicosis Patients' Perception and Social Implications of Arsenic Poisoning through Groundwater in Bangladesh. - Int. J. Environ. Res. Public Health 7: 3644-3656.

[125] Saunders, J. A., Lee, M.-K., Uddin, A., Mohammad, S., Wilkin, R. T., Fayek, M., Korte, N. E. (2004): Natural arsenic contamination of Holocene alluvial aquifers by linked tectonic, weathering, and microbial processes. - Geochemistry Geophysics Geosystems 6.

[126] Seidel, A., Waypa, J. J., Elimech, M. (2001): Role of charge (Donnan) exclusion in removal of arsenic from water by a negatively charged porous nanofiltration membrane. Environ. Eng. Sci. 18: 105-113.

[127] Sen Gupta, B., Chatterjee, S., Rott, U., Kauffman, H., Bandopadhyay, A., De Groot, W., Nag, N. K., Carbonell-Barrachina, A. A., Mukherjee, S. (2009): A simple chemical free arsenic removal method for community water supply - a case study from West Bengal, India. - Environ.Pollut. 157: 3351-3353.

[128] Shankar, S., Shanker, U., Shikha (2014): Arsenic Contamination of Groundwater: A Review of Sources, Prevalence, Health Risks, and Strategies for Mitigation. - The Scientific World Journal, Article ID 2014;304524, 18 pages.

[129] Sharma, V. K. (2007a): A review of disinfection performance of $\mathrm{Fe}(\mathrm{VI})$ in water and waste water. - WaterSci.Technol. 55: 225-230.

[130] Sharma, V. K. (2007b): Ferrate studies for disinfection and treatment of drinking water. In: Nikolaou, A., Rizzo, L., Selcuk, H. (eds.) Advances in Control of Dis-infection By products in Drinking Water Systems. Nova Science Publishers, USA pp. 1-6.

[131] Sharma, V. K., Burnet, C. R., Yngard, R., Cabelli, D. E. (2005a): Iron(VI) and iron (V) oxidation of copper(I) cyanide. - Environ.Sci.Technol. 39: 3849-3855.

[132] Sharma, V. K., Kazama, F., Jiangyong, H., Ray, A. K. (2005b): Ferrates as environmentally-friendly oxidants and disinfectants. - J.WaterHealth 3: 42-58.

[133] Sharma, V. K., Dutta, P. K., Ray, A. K. (2007): Review of kinetics of chemical and photocatalytical oxidation of Arsenic(III) as influenced by $\mathrm{pH}$. - Journal of Environmental Science and Health 42(7): 997-1004.

[134] Sharma, V. K, Sohn, M. (2009): Aquatic arsenic: toxicity, speciation, transformations, and remediation. - Environ.Int. 35: 743-759.

[135] Shen, Y., Sun, D., Zhao, X., Yu, G. (2005): Screening report in areas of endemic arsenismand high content of As in China. - Chin. J. Endemiology 24: 172-175. (in Chinese).

[136] Sheng, J., Bingzhi, X., Zhanga, Q., Xua, B., Gaoa, N., Causserandab, C. (2007): Study of arsenic removal by nano-filtration and its application in China. https://doi.org/10.1016/j.desal.2006.04.035.

[137] Shi, W. D., Guo, J. Q., Zhang, S. Q., Ye, C. M., Li, J., Ma, X. H. (2010): The distribution and geochemistry of geothermal groundwater bearing $\mathrm{F}$ and As in the Guide Basin.Hydrogeol. Eng. Geol. 37: 36-41. (in Chinese).

[138] Shih, M. C. (2005): An overview of arsenic removal by pressure-driven membrane processes. - Desalination 172: 85-97.

[139] Shukla, D. P., Dubey, C., Singh, N. P., Tajbakhsh, M., Chaudhry, M. (2010): Sources and controls of arsenic contamination in ground water of RajnandgaonandKanker District, Chhattisgarh, Central India. - J.Hydrol. 395: 49-66. 
[140] Singh, T. S., Pant, K. K. (2004): Equilibrium, kinetics and thermodynamic studies for adsorption of As(III) on activated alumina. - Separation and Purification Technology 36(2): 139-147.

[141] Smedley, P. L., Kinniburgh, D. G. (2002): A review of the source, behavior and distribution of arsenic in natural waters. - Appl. Geochem. 17: 517-568.

[142] Smedley, P. L., Zhang, M., Zhang, G., Luo, Z. (2003): Aquifers and Arsenic Mobilization in the Huhhot Basin, Inner Mongolia. - Appl. Geochem. 18: 1453-1477.

[143] Smith, A. H., Lingas, E. O., Rahman, M. (2000): Contamination of drinking-water by arsenic in Bangladesh: a public health emergency. - Bull. W.H.O. 78: 1093-1103.

[144] Song, S., Lopez-Valdivieso, A., Hernandez-Campos, D. J., Peng, C., Monroy-Fernandez, M. G., Razo-Soto, I. (2006): Arsenic removal from high-arsenic water by enhanced coagulation with ferric ions and coarse calcite. - Water Research 40(2): 364-372.

[145] Song, J., Zhang, M., Figoli, A., Yin, Y., Zhao, B., Li, X.-M., He, T. (2015): Arsenic removal using a sulfonated poly(ether ether ketone) coated hollow fiber nanofiltration membrane. - DOI:10.1039/C5EW00109A.

[146] Sun, G.-F., Li, X., Zhou, J.-Y. (2003): Study of using 10\% sampling method to identify the high arsenic exposure area. - Chin J Dis ContrPrev. 7: 480-483.

[147] Sun, G. (2004): Arsenic contamination and arsenicosis in China. - Toxicol. Appl. Pharmacol. 198: 268-271.

[148] Sun, G., Xu, Y., Zheng, Q., Xi, S. (2011): Arsenicosis history and research progress in Mainland China. - Kaohsiung Journal of Medical Sciences.

[149] Sun, X., Hu, C., Hu, X., Qu, J., Yang, M. (2013): Characterization and adsorption performance of Zr-dopedakaganèite for efficient arsenic removal. - J.Chem.Technol. Biotechnol. 88: 629-635.

[150] Swarnkar, V., Tomar, R. (2012): Use of surfactant-modified zeolites for arsenate removal from pollutant water. - J.Dispers.Sci.Technol. 33: 913-918.

[151] SWI. (2012): Water forum seeks solutions to global crisis. - Available on: https://www.swissinfo.ch/eng/water-forum-seeks-solutions-to-global-crisis/32299242.

[152] Tang, J., Bian, J. M., Li, Z.-Y., Wang, C. Y. (2010): Inverse geochemical modeling of high arsenic groundwater: a case study of the arsenic endemic area in western Jilin Province. - Geol. China 37: 754-759. (in Chinese with English abstract).

[153] Thakur, J. K., Thakur, R. K., Ramanathan, A. L., Kumar, M., Singh, S. K. (2011): Arsenic contamination of ground water in Nepal - an overview. - Water 3: 1-20.

[154] Tripathy, S. S., Raichur, A. M. (2008): Enhanced adsorption capacity of activated alumina by impregnation with alum for removal of $\mathrm{As}(\mathrm{V})$ from water. - Chem. Eng.J. 138: $179-186$.

[155] Tseng, W. P., Chu, H. M., How, S. W., Fong, J. M., Lin, C. S., Yeh, S. (1968): Prevalence of skin cancer in an endemic area of chronic arsenicism in Taiwan. - J. Natl. Cancer Inst. 40: 453-463.

[156] Unicef (2013): Available on: https://www.unicef.org/eap/.

[157] USEPA. (2000): Technologies and Costs for Removal of Arsenic from Drinking Water. Ground Water and Drinking Water Office, United States Environmental Protection Agency: Washington, DC, USA, 2000. Available online: www.epa.gov/ogwdw/arsenic/pdfs/treatments_and_costs.pdf.

[158] USEPA. (2000): Risk based Concentration Table. - United States Environmental Protection Agency, Philadelphia, PA; Washington DC.

[159] Van Halem, D., de Olivero, S., Vet, W., Verberk, J., Amy, G. L., van Dijk, J. C. (2010): Subsurface iron and arsenic removal for shallow tube well drinking water supply in rural Bangladesh. - Water Res. 44: 5761-5769.

[160] Visoottiviseth, P., Ahmed, F. (2008): Technology for remediation and disposal of arsenic. - Rev. Env.Contam. Toxicol. 197: 77-128. 
[161] Wang, L., Sun, X., Xu, X. (1993): Investigation on relationship between water arsenic and endemic arsenism in Kuitun Reclamation Area, Xinjiang, China. - Endem. Dis. Bull. 8: 88-92. (in Chinese).

[162] Wang, S. X., Wang, Z. H., Cheng, X. T., Li, J., Sang, Z. P., Zhang, X. D., Han, L. L., Qiao, X. Y., Wu, Z. M., Wang, Z. Q. (2007): Arsenic and Fluoride Exposure in Drinking Water: Children's IQ and Growth in Shanyin County, Shanxi Province, China. doi:10.1289/ehp.9270.

[163] Wang, Y., Shvartsev, S. L., Su, C. (2009): Genesis of arsenic/fluoride-enriched soda water: a case study at Datong, northern China. - Appl. Geochem. 24(4): 641-649.

[164] Wang, Y. X., Su, C. L., Xie, X. J., Xie, Z. M. (2010): The genesis of high As groundwater: a case study in Datong Basin. - Geol. China 37: 771-780. (in Chinese with English abstract).

[165] Water research about removal of arsenic. - Available online on the website: http://gadgillab.berkeley.edu/research/water/arsenic_removal/

[166] Wegelin, M., Gechter, D., Hug, S., Mahmud, A., Motaleb, A. (2000): SORAS-a simple arsenic removal process. - http://phys4.harvard.edu/wilson /mitigation/SORAS Paper.html.

[167] Wen, D., Zhang, F., Zhanga, E., Wang, C., Han, S., Zheng, Y. (2013): Arsenic, fluoride and iodine in groundwater of China. - Journal of Geochemical Exploration, dx.doi.org/10.1016/j.gexplo.2013.10.012.

[168] Wilkie, J. A., Hering, J. G. (1996): Adsorption of arsenic onto hydrous ferric oxide: effects of adsorbate/adsorbent ratios and co-occurring solutes. - Colloids and Surfaces A: Physicochemical and Engineering Aspects. 107: 97-110.

[169] World Health Organization WHO. (1999): Arsenic in Drinking Water. - Fact Sheet No. 210 .

[170] World Health Organization WHO. (2004): List of countries are having arsenic issues. Available on: https://www.who.int/whr/2004/en/.

[171] World Health Organization WHO. (2011): Guidelines for Drinking-Water Quality.vol.4. - World Health Organisation, Geneva, pp.315-318. Available on: https://www.who.int/water_sanitation_health/publications/drinking-water-qualityguidelines-4-including-1st-addendum/en/.

[172] Xi, B., Wang, X., Liu, W., Xia, X., Li, D., He, L., Wang, H., Sun, W., Yang, T., Tao, W. (2014): Fluoride and Arsenic Removal by Nano-filtration Technology from Groundwater in Rural Areas of China: Performances with Membrane Optimization. - Separation Science and Technology 49(17): 2642-2649. DOI: 10.1080/01496395.2014.939761.

[173] Xie, X., Wang, Y., Su, C., Liu, H., Duan, M., Xie, Z. (2008): Arsenic mobilization in shallow aquifers of Datong Basin: hydrochemical and mineralogical evidences. - J. Geochem. Explor. 98: 107.

[174] Xie, X., Ellis, A., Wang, Y., Xie, Z., Duan, M., Su, C. (2009a): Geochemistry of redoxsensitive elements and sulfur isotopes in the high arsenic groundwater system of Datong Basin, China. - Science of The Total Environment 407: 3823-3835.

[175] Xie, X., Wang, Y., Duan, M., Xie, Z. (2009b): Geochemical and environmental magnetic characteristics of high arsenic aquifer sediments from Datong Basin, northern China. Environmental Geology 58: 45-52.

[176] Xie, X. J., Wang, Y. X., Ellis, A., Su, C. L., Li, J. X., Li, M. D. (2011a): The sources of geogenic arsenic in aquifers at Datong basin, northern China: constraints from isotopic and geochemical data. - J. Geochem. Explor. 110: 155-166.

[177] Xie, Z. M., Wang, Y. X., Duan, M. Y., Xie, X. J., Su, C. L. (2011b): Arsenic release by indigenous bacteria Bacillus cereus from aquifer sediments at Datong Basin, northern China. - Front. Earth Sci. 5: 37-44.

[178] Xie, X., Wang, Y., Su, C., Li, J., Li, M. (2011c): Influence of irrigation practices on arsenic mobilization: Evidence from isotope composition and $\mathrm{Cl} / \mathrm{Br}$ ratios in groundwater 
from Datong Basin northern China. - Journal of Hydrology 424-425: 37-47. doi:10.1016/j.jhydrol.2011.12.017.

[179] Xie, X., Johnson, T. M., Wang, Y., Lundstrom, C. C., Ellis, A., Wang, X., Duan, M. (2012): Mobilization of arsenic in aquifers from the Datong Basin, China: evidence from geochemical and iron isotopic data. - Chemosphere 90(6): 1878-1884.

[180] Xie, X., Wang, Y., Ellis, A., Su, C., Li, J., Li, M., Duan, M. (2013): Delineation of groundwater flow paths using hydrochemical and strontium isotope composition: A case study in high arsenic aquifer systems of the Datong basin, northern China. - Journal of Hydrology 476(7): 87-96.

[181] Xie, X., Wang, Y., Pi, K., Liu, C., Li, J., Liu, Y., Wang, Z., Duan, M. (2015): In situ treatment of arsenic contaminated groundwater by aquifer iron coating: Experimental study. - DOI: 10.1016/j.scitotenv.2015.05.002.

[182] Yang, S. Z., Guo, H. M., Tang, X. H (2008): Distribution of abnormal groundwater arsenic in Hetao Plain, Inner Mongolia. - Earth Sci. Front. 15: 242-249. (in Chinese with English abstract).

[183] Yang, G. R., Ye, F., Yang, C. G., Zhang, H. W., Wang, A. W., Huang, W. L., Peng, H. B. (2011): The first analysis for results of water arsenic screening in Yunnan. - Chin. J. Control Endem. Dis. 26: 43-45.

[184] Yoon, S.-H., Lee, J. H. (2005): Oxidation mechanism of As (III) in the UV/TiO2 system: evidence for a direct whole oxidation mechanism. - Environmental Science and Technology 39(24): 9695-9701.

[185] Young, E. (1996): Cleaning up arsenic and old waste. - New Scientist: 22.

[186] Yu, G. Q., Sun, D. J., Zheng, Y. (2007): Health effects of exposure to natural arsenic in groundwater and coal in China: an overview of occurrence. - Environ. Health Perspect. 115: 636-642.

[187] Yunus, M., Sohel, N., Hore, S. K., Rahman, M. (2011): Arsenic exposure and adverse health effects: A review of recent findings from arsenic and health studies in Matlab, Bangladesh. - Kaohsiung J. Medical Sci. 27: 371-376.

[188] Zhang, L. H., Guo, Q. H. (2007): Hydrothermal systems Hengduan Mountains, China. In: Bullen, T. D., Wang, Y. (eds.) Water-Rock Interaction. Proceedings of the $12^{\text {th }}$ International Symposium on water-rock interaction. Taylor \& Francis, London. Volumes 1-2,. pp. 1299-1303.

[189] Zhang, Y., Wang, W., Wang, L., Miao, Q. (2010): The geological environment characteristics and distribution of groundwater arsenic in the typical section of Hetao Plain. - J. Arid Land Resour. Environ.: 167-171. (in Chinese with English abstract).

[190] Zheng, Y. (2007): The heterogeneity of arsenic in the crust: a linkage to occurrence in groundwater. - Quaternary Sciences 27: 6-19.

[191] Zheng, Y. (2017): Lessons Learned from Arsenic Mitigation among Private Well Households. - Curr Environ Health Rep. 4(3): 373-382. doi: 10.1007/s40572-017-0157-9.

[192] Zhou, L. F., Zhu, Y., Cui, X. F., Xie, W. P., Hu, A. H., Yin, K. S. (2006): Arsenic trioxide, a potent inhibitor of $\mathrm{NF}-\kappa \mathrm{B}$, abrogates allergen-induced airway hyperresponsiveness and inflammation. - Respiratory Research 7:146. https://doi.org/10.1186/1465-9921-7-146.

[193] Zhu, Y. L., Zheng, Y. J., Chen, X. (2009): Characteristics of mineral element concentrations in the drinking waters of regions with and without endemic arsenism disease in Quitun, Xinjiang. - J. Xinjiang Med. Univ. 32: 247-248.

[194] Zhu, J., Pigna, M., Cozzolino, V., Caporale, A. G., Violante, A. (2013): Higher sorption of arsenate versus arsenite on amorphous Aloxide, effect of ligands. - Environmental Chemistry Letters 11(3): 289-294. 


\section{APPENDIX}

Table S1. Arsenic affected areas in China

\begin{tabular}{|c|c|c|c|c|}
\hline \multirow{2}{*}{ S.NO } & \multirow{2}{*}{ PROVINCES } & \multirow{2}{*}{$\operatorname{Max} \operatorname{As}(\mu \mathrm{g} / \mathrm{L})$} & \multicolumn{2}{|c|}{ Coordinates in decimal } \\
\hline & & & Lat & Long \\
\hline 1 & Anhui & 1146 & 31.833333 & 117 \\
\hline 2 & Beijing & 143 & 39.916667 & 116.383333 \\
\hline 3 & Guangdong & 21 & 23.4 & 113.5 \\
\hline 4 & Gansu & $\geq 250$ & 38 & 102 \\
\hline 5 & Henan & $\geq 500$ & 33.9 & 113.5 \\
\hline 6 & Hunan & $\geq 50$ & 27.4 & 111.8 \\
\hline 7 & Helongjiang & 200 & 48 & 129 \\
\hline 8 & Inner Mogolia & 1860 & 44 & 113 \\
\hline 9 & Jilin & $\geq 500$ & 43.7 & 126.2 \\
\hline 10 & Jiangsu & 333 & 32.9 & 119.8 \\
\hline 11 & Liaoning & 25 & 41.1 & 122.3 \\
\hline 12 & Niangxia & 177 & 36.6 & 105.32 \\
\hline 13 & Qinghai & 318 & 35 & 96 \\
\hline 14 & Sichuan & 287 & 30.133333 & 102.933333 \\
\hline 15 & Shandong & $\geq 50$ & 36.4 & 118.4 \\
\hline 16 & Shanxi & 1932 & 37.7 & 112.4 \\
\hline 17 & Taiwan & 600 & 25.033333 & 121.633333 \\
\hline 18 & Xinjinag & 830 & 41 & 85 \\
\hline 19 & Yunnan & 687 & 25.05 & 101.866667 \\
\hline 20 & Zhejiang & 80 & 29.2 & 120.5 \\
\hline
\end{tabular}

